Notre Dame Law School

NDLScholarship

\title{
Law and Governance Affecting the Resolution of Academic and Disciplinary Disputes at Scottish Universities: An American Perspective
}

Fernand N. Dutile

Notre Dame Law School, fernand.n.dutile.1@nd.edu

Follow this and additional works at: https://scholarship.law.nd.edu/law_faculty_scholarship

Part of the Comparative and Foreign Law Commons, Dispute Resolution and Arbitration Commons, and the Education Law Commons

\section{Recommended Citation}

Fernand N. Dutile, Law and Governance Affecting the Resolution of Academic and Disciplinary Disputes at Scottish Universities: An American Perspective, 8 Ind. Int'l \& Comp. L. Rev. 1 (1997-1998).

Available at: https://scholarship.law.nd.edu/law_faculty_scholarship/794 


\title{
LAW AND GOVERNANCE AFFECTING THE RESOLUTION OF ACADEMIC AND DISCIPLINARY DISPUTES AT SCOTTISH UNIVERSITIES: AN AMERICAN PERSPECTIVE
}

\author{
Fernand N. Dutile*
}

\section{INTRODUCTION}

At the entrance to St. Mary's College, a part of the University of St. Andrews in Scotland, one encounters the opening words of the Gospel of St. John: "In principio erat verbum." Eschewing the usual translation, ${ }^{2}$ students there irreverently render the passage thus: "The Principal has the last word." ${ }^{3}$ The existence of the position of Principal in a university and the substantial power of that official cause only part of the fascination experienced by the American observer of universities in Scotland. This article will assess, from an American perspective, the law and governance affecting the resolution of academic and disciplinary disputes involving students at Scottish universities. This analysis will reflect the many ways in which the treatment of such disputes in Scotland both differs from and resembles their treatment in the United States. ${ }^{4}$ In a compromise of manageability and comprehensiveness, the eight (of thirteen) ${ }^{5}$ Scottish universities first constituted provide the focus for this Article. ${ }^{6}$ Among those

* Associate Dean and Professor of Law, Notre Dame Law School; A.B., Assumption College, 1962; J.D., University of Notre Dame, 1965; Admitted to the Maine Bar, 1965.

The author did much of the research for this article as a Senior Visiting Fellow at the University of Aberdeen (Scotland) during the summer of 1996. He is deeply indebted to Christopher H. W. Gane, Professor of Scots Law and Dean of the Faculty of Law at the University of Aberdeen, for making that appointment possible and the period in residence both productive and enjoyable. The author thanks as well all those who provided information, oral or written, to this project; many of them are cited in footnotes to this piece. Thanks go also to my secretary, Nancy Beaudoin, for her good help. A research grant from the Notre Dame Law School greatly facilitated my work in Scotland.

1. St. John $1: 1$.

2. "In the beginning was the Word."

3. Interview with Frank Quinault, Hebdomadar, Univ. of St. Andrews, in St. Andrews, Scot. (July 18, 1996).

4. For a similar study regarding Australian universities, see Fernand N. Dutile, Law, Governance, and Academic and Disciplinary Decisions in Australian Universities: An American Perspective, 13 ARIZ. J. INT'L. \& CoMP. L. 69 (1996).

5. See infra text accompanying note 18.

6. The eight universities are St. Andrews, with 5,414 students in 1994-95, UNIVERSITY OF ST. ANDREWS, PROSPECTUS 1996 ENTRY, at 8; Glasgow, with 16,555 students in 1994-95, UNIVERSITY OF GLASGOW, FACTS AND FIGURES: 1995; Aberdeen, with 9,650 students, EDUCATION YEARBOOK 1995/96, at 349; Edinburgh, with 15,208 students, UNIVERSITY OF EDINBURGH, FACTS AND FIGURES: 1995; Strathclyde, with 12,600 students in 1994-95, interview with Susan Mellows, Academic Registrar, Univ. of Strathclyde, in Glasgow, Scot. (July 5, 1996) [hereinafter Mellows Interview]; Heriot-Watt, with 4,500 students in 1995-96, interview with Ralph Parkinson, Senior Assistant Secretary, Heriot-Watt Univ., in Edinburgh, 
eight, the University of Aberdeen, at which the author did most of the research for this piece, garners particular attention.

Scotland is the northern constituent part of the United Kingdom. This resulted from the union of its Parliament with that of England under the Treaty of Union in 1707, just over a century after the union of the crowns of these two countries. ${ }^{7}$ Though not a state, to this day most Scots consider Scotland a nation. ${ }^{8}$ Today, Scotland has a population well over $5,000,000 .{ }^{9}$

Three of Scotland's universities, recognized as such by papal decree, ${ }^{10}$ date from before the Reformation: St. Andrews, founded in 1411; Glasgow, founded in 1451; and Aberdeen, founded in 1494. Because, early on, Scots tended to seek higher education on the Continent rather than in the south of Britain, Scottish education took on a European rather than an English tradition; accordingly, these three universities reflected the "studentled pattern of Bologna rather than the master-dominated pattern of Oxford." 11 This pattern builds on the idea of an academic community, with students as full-fledged members carrying rights and responsibilities. ${ }^{12} \mathrm{King}$ James VI of Scotland-later to be James I of England-chartered the University of Edinburgh, founded in 1583 as the first post-Reformation university in the country. ${ }^{13}$ These four so-called "ancient universities"14

Scot. (July 19, 1996) [hereinafter Parkinson Interview]; Dundee, with 6,498 students, EDUCATION YEARBOOK 1995/96, at 349; and Stirling, with 5,200 students, interview with Dennis Farrington, Deputy Secretary and Clerk to the Court, Univ. of Stirling, in Stirling, Scot. (July 4, 1996) [hereinafter Farrington Interview].

Comparisons with specific American universities appear principally in the footnotes. These comparisons focus on two large public universities-the University of Michigan and Indiana University (at Bloomington). In the fall of 1994, the University of Michigan enrolled 36,543 students, the fourteenth largest enrollment in the United States; Indiana University enrolled 35,594, the seventeenth largest enrollment in the United States. CHRON. OF HIGHER EDUC.: AlmanAC ISSUE, Sept. 2, 1996, at 16. Much of the information relating to the University of Michigan and to Indiana University first appeared in Dutile, supra note 4, passim.

7. The CAMbridge EnCyClopedia 987 (David Crystal ed., 2d ed. 1994).

8. ROBIN M. White \& IAN D. WILLOCH, THE SCOTTISH LEGAL SYSTEM 6 (1993).

9. THE CAMBRIDGE ENCYCLOPEDIA, supra note 7, at 986.

10. At Aberdeen, for example, "the Papal Bull of February 10, 1495 granted by Pope Alexander VI (Roderigo Borgia) on the petition of King James IV of Scotland erected a studium generale and university for the study of, inter alia, civil law." Michael C. Meston, The Civilists of Aberdeen: 1495-1995, 1995 JURID. REV. 153, 153.

11. Collins ENCYCLOPAEDIA OF SCOTLAND 346 (John Keay \& Julia Keay eds., 1994).

12. UNIVERSITY OF STIRLING, HANDBOOK FOR STUDENTS 3 (1995-96) [hereinafter STIRLING HANDBOOK].

13. AsSOCIATION OF COMMONWEALTH UNIV., 2 COMMONWEALTH UNIVERSITIES YEARBOOK 1290 (1995-96).

14. Charles Henderson \& Frank Mattison, Universities and the Law, in CoNFERENCE OF UNIVERSITY ADMINISTRATORS, UNIVERSITIES AND THE LAW 9 (Dennis Farrington \& Frank Mattison eds., 1990). They are referred to as "the older Universities" in THE UNIVERSITIES 
stood alone until well into the twentieth century. In the 1960 s, four new universities were constituted (the University of Strathclyde in 1964, HeriotWatt University in 1966, and both the University of Dundee and the University of Stirling in 1967). These four universities are controlled by Royal Charter. ${ }^{15}$ Only one of these four, the University of Stirling, was wholly new, ${ }^{16}$ the other three having evolved from pre-existing institutions. ${ }^{17}$ Finally, in 1992-93, five new universities, all descendants of former colleges, emerged (Abertay, Napier, Robert Gordon, Paisley and Glasgow Caledonian). ${ }^{18}$ For the 1993-94 academic year, Scotland boasted a total of 68,004 full-time university students, of whom 58,637 were undergraduates. ${ }^{19}$ Some universities have faced enormous growth; the student population at St. Andrews, for example, grew over fifty percent from 1986 to $1996 .{ }^{20}$

Until 1988, the government did not exert control over universities legislatively; usually, Parliament applied to universities the laws pertaining to any large public employer or occupier of land. ${ }^{21}$ Rather, it exerted its control through the power of the purse and through advice to the University Grants Committee (UGC). ${ }^{22}$ The UGC played a formidable role in the history of universities in the United Kingdom, operating as a buffer between

(SCOTLAND) ACT 1966, § 16(1).

15. STIRLING HANDBOOK, supra note 12 , at 3 . The remaining universities find themselves subject to either Parliamentary control (Aberdeen, Edinburgh, Glasgow and St. Andrews, which were reformed in the nineteenth century), or to government Order pursuant to the Further and Higher Education (Scotland) Act of 1992 (the others). Id. Higher education in the United Kingdom now manifests about "ten different and distinct models for governance . . . ." Dennis J. Farrington, Students as Customers of UK Higher Education 1 (1996) (unpublished manuscript, on file with author). Schools and colleges fall within the control of the Scottish Education Department, one of five departments of the Scottish Office, which the Secretary of State for Scotland heads. ENID MARSHALL, GENERAL PRINCIPLES OF SCOTS LAW 252 (6th ed. 1995).

16. See STIRLING HANDBOOK, supra note 12.

17. DENNIS FARRINGTON, THE LAW OF HIGHER EDUCATION 7-8 (1994).

18. See STIRLING HANDBOOK, supra note 12.

19. UNIVERSITIES' STATISTICAL RECORD, 1 UNIVERSITY STATISTICS 1993-94: STUDENTS AND STAFF 15. (Of course, thousands of students study at other higher-education institutions, beyond universities, in Scotland. See Collins ENCYClOPAEDIA OF SCOTLAND, supra note 11 , at 345.) In the universities, women are less well represented at the graduate level than at the undergraduate. Of the 9,367 graduate students, 3,301-or 35\%-were women. At the undergraduate level, 27,685 (or $47 \%$ ) of the 58,637 students were women. 1 UNIVERSITY STATISTICS 1993-94, supra.

In Scotland, undergraduates generally earn, as their first degree, a master's degree with honours, a course of study which normally spans four years; the three-year ordinary (or general) pass degree forms the main exception. 2 COMMONWEALTH UNIVERSITIES YEARBOOK, supra note 13, at 1295.

20. Frank Quinault, A Review of Student Support at St. Andrews 1 (1996).

21. FARRINGTON, supra note 17 , at 86-87.

22. Henderson \& Mattison, supra note 14 , at 13. 
the government and academe. Thus could it, over a long period of time, minimize governmental interference into the scholarly world. Moreover, the UGC exercised enormous leadership in supervising the extraordinary expansion of higher education after World War II. Ultimately, however, the UGC became "increasingly intrusive" through extensive questionnaires and investigations regarding university finances and other matters and through actions based on the ensuing findings. ${ }^{23}$ Established in 1989 as the successor to the UGC, the Universities Funding Council (UFC) has wielded a less peremptory style, though perhaps not substance; it has made its pronouncements "in the form of 'advice,' but the explicit penalty for not adopting them was loss of funds."24

British universities secure their financing, directly or indirectly, largely under governmental auspices. ${ }^{25}$ This funding appears in three forms: 1) external research income; 2) the block grant, provided to universities by the Department for Education through national funding councils; and 3) tuition fees, set by government and paid by students' local authority. ${ }^{26}$ Meanstested maintenance grants remain available to students, but their real value has eroded over the years and the government has decided to replace these grants with low-interest loans. ${ }^{27}$ In light of the overall reduction in the government's willingness to support universities, some educational officials have proposed that universities charge students extra fees, a proposal the government has seriously studied. ${ }^{28}$ Nonetheless, a better-than-expected budget for 1997-98, a reflection of the government's recognition of the funding crisis facing British universities, probably puts off the necessity for tuition charges at British universities. ${ }^{29}$

Universities in the United Kingdom have no formal organization through which to present "the university view." The Committee of ViceChancellors and Principals (CVCP), however, has informally established itself as the sole player of this role, which it secured more "by default than by intention." 30 Its membership (still theoretically voluntary) of over one hundred comprises the chief executives of universities in England and Wales (Vice-Chancellors) and in Scotland (Principals). This committee operates in three important ways: 1) as a forum for discussion of universities' common

23. 2 COMMONWEALTH UNIVERSITIES YEARBOOK, supra note 13, at 1293.

24. Id. at 1292-93.

25 . Roughly $80 \%$ of the universities' funding comes from the government through the UFC. COLLINS ENCYCLOPAEDIA OF SCOTLAND, supra note 11, at 346. "[Universities'] resources, and thus their policies, are therefore largely dependent on national will . . . " Id.

26. 2 COMMONWEALTH UNIVERSITIES YEARBOOK, supta note 13, at 1294.

27. Id.

28. Id. at 1294-96.

29. Chron. OF Higher Educ., Dec. 13, 1996, at A46.

30. 2 COMMONWEALTH UNIVERSITIES YEARBOOK, supra note 13, at 1293. 
problems; 2 ) as a collector and distributor (including with regard to lobbying and other public relations) of information for and about universities; and 3) as a service center for universities. ${ }^{31}$

\section{UNIVERSITY GOVERNANCE}

\section{A. The Governing Boards}

\section{The University Court}

Ultimate power in Scottish universities lies with the university Court, ${ }^{32}$ as it has for well over a century. ${ }^{33}$ The Universities (Scotland) Act of 1858 established university Courts ${ }^{34}$ to "counterbalance the power of the generally very conservative Senates . . . " 35 Generating greater university accountability to the public also drove the creation of these Courts. ${ }^{36}$ The 1858 Act gave university Courts, among other things, power to review all decisions of the university Senate and to "effect improvements in the internal arrangements of the University . . . ." ${ }^{37}$ The Universities (Scotland) Act of 1889 brought additional power to the Courts, including the power to administer "the whole revenue and property" of the university ${ }^{38}$ and to appoint members of the academic staff. ${ }^{39}$ Later legislation added to and

31. See id. Through specialized agencies, it collects and processes statistics, provides admissions support, conducts collective bargaining with trade unions, and does many other things. Id.

32. See, e.g., ChaRTER § 8(1), in UNIVERsity of STIRLING, CALENDAR 64 (1995-96) ("There shall be a Court . . . which . . . shall be the governing body of the University."); Charter § 7(1), in UNIVERSITY OF DUNDEE, CaLENDAR 150 (1994-96) ("There shall be a Court . . . which . . . shall be the Governing Body of the University.") To the same effect, see CHARTER OF HERIOT-WATT UNIVERSITY $§ 8(1)$ (1966) (amended 1981).

33. Of course, some of its actions must be approved by the Crown. See, e.g., THE UNIVERSITIES (SCOTLAND) ACT 1966, § 4(1)(e). So too with regard to some actions at universities created in the twentieth century by Royal Charter. See, e.g., ChARTER OF HERIOT-WATT UNIVERSITY $\S 24(1)$.

34. Collins ENCYClopaedia of SCOTLAND, supra note 11, at 347.

35. E. J. Powell, The History of the Rectorship $\$ 2.2$ (1993) (unpublished manuscript, on file with author).

36. Id.

37. THE UNIVERSITIES (SCOTLAND) ACT $1858, \S 5$.

38. THE UNIVERSITIES (SCOTLAND) ACT $1889, \S 6(1)$.

39. Id. § 6(4). The legislation also empowers the Court to "take proceedings against" any member of the academic staff and to call any member of the University to give evidence in the matter. Id. $\S 6(6)$.

The governing board of the University of Michigan has "general supervision of [the] institution and the control and direction of all expenditures from the institution's funds." MiCH. CONST. art. VIII, \& 5. (The same applies to Michigan State University and Wayne State University. Id.) See also Mich. CoMP. LAwS ANN. \$390.3 (West 1995). The board 
refined the powers of Courts at the older universities. ${ }^{40}$ Royal Charters created the Courts and their powers at some later universities. ${ }^{41}$

At the University of Aberdeen, the University Court, created by the 1858 legislation, at first comprised the Rector, ${ }^{42}$ the Principal, ${ }^{43}$ and assessors (four in all) nominated-one each-by the Chancellor, ${ }^{44}$ the Rector, the Senate, ${ }^{45}$ and the General Council ${ }^{46}$ The 1889 legislation enlarged the Court's membership to include the Lord Provost of Aberdeen and the Town Council's assessor. Raising the membership of the Court to fourteen, the Act provided three additional assessors to the Senate and three additional assessors to the General Council. The Universities (Scotland) Act of 1966 added to the governing board a number of members drawn from the nonprofessorial staff. In 1975, the nominees of the District Council of the City of Aberdeen and of the Grampian Regional Council, respectively, replaced the Lord Provost of Aberdeen and the Town Council's assessor in the

of regents of the University of Michigan has the entire control and management of university affairs. Indeed, its control over expenditures is quite remarkable; the legislature may attach conditions only upon the money it appropriates to the University and, although these conditions bind the governing board once it accepts the money, such conditions may not interfere with the regents' management of the University. Sprik v. Regents of the Univ. of Mich., 204 N.W.2d 62 (1972).

For more specific allocations of power, see MICH. COMP. LAws ANN. $\$ 390.5$ (West 1995) (power to enact ordinances, by-laws, and regulations and to appoint academic staff and set their salaries); $\S 390.6$ (power to remove the President or any professor or tutor); and $\S$ 390.891 (power to establish parking, traffic, and pedestrian ordinances).

For the plenary powers of the board of trustees at Indiana University, see IND. CODE ANN. §§ 20-12-1-1 et seq., and §§ 20-12-23-2, -7 (West 1995). The board acts in the dual capacity of directors and managers of the University and as trustees of the trusts created by private donors. Sendak v. Indiana Univ., 260 N.E.2d 601 (1970).

40. See The UNIVERsities (SCOTLAND) ACT 1932, § 2; and ThE UNIVERSITIES (SCOTLAND) ACT 1966, § 3(1) and Schedule 2. For a good summary of the current power of the University Court at Glasgow, see UNIVERSITY OF GLASGOW: HISTORY AND CONSTITUTION viii (1977). See also UNIVERSITY OF EDINBURGH, CALENDAR, A-23 (1995-96) [hereinafter EDINBURGH CALENDAR].

41. See, e.g., CharTer of HeRIOT-WATT UNIVERSITY $\$ \$ 8,21,22,24$; CharTER (SCHEDULE) $\S 9(5)$, in UNIVERSITY OF DUNDEE, CALENDAR 160-63 (1994-96) [hereinafter Dundee Calendar]; Charter \& 8(1), in University OF STIRling, Calendar 64 (1995-96) [hereinafter STIRLING CALENDAR]; CHARTER OF HERIOT-WATT UNIVERSITY (SCHEDULE), STATUTE IX, §8.

42. See infra text accompanying notes $125-78$ for more information on the office of Rector.

43. See infra text accompanying notes $119-24$ for more information on the office of Principal.

44. See infra text accompanying notes $108-18$ for more information on the office of Chancellor.

45. See infra text accompanying notes $68-91$ for more information on the Senate.

46. See infra text accompanying notes $92-103$ for more information on the General Council. 
Court's membership. Finally, subsequent changes brought to the Court three Vice-Principals, two additional assessors elected from among its membership by the Senate, the President of the Students' Representative Council, and up to six co-opted members, of whom not more than one may hold an appointment in the University. ${ }^{47}$

Despite the relatively broad representation, the Court at Aberdeen-unlike the governing boards at many American universities ${ }^{48}$-boasts a strong campus presence; even some of the members who themselves do not hold campus positions may be selected by campus constituencies. The Rector, for example, who chairs the Court at Aberdeen, ${ }^{49}$ is elected by the students. ${ }^{50}$ The concentration of campus influence within the Court enables it to remain attuned to, and interested in,

47. UNIVERSITY OF ABERDEEN, CALENDAR 7-9 (1995-96) [hereinafter ABERDEEN CALENDAR]. For the membership of the Court at other "older" universities, see UNIVERSITY OF ST. ANDREWS, Calendar 2.2 (1994-95) [hereinafter ST. ANDREWS Calendar]; EDINBURGH CALENDAR, supra note 40, at A-23.

At the University of Stirling, a newer university, the Court comprises up to twenty-three members: the chair (a layperson); four academic members appointed by the Academic Council; two academic members appointed by the Academic Assembly; the Principal and two Vice-Principals, ex officio; and laypersons appointed by local government, the Conference of the University, the Graduates' Association, the Chancellor, and the Court itself. The President and the Honorary President of the Students' Association represent the students. UNIVERSITY OF STIRLING, HANDBOOK FOR STUDENTS 3 (1995-96). For the membership of the Court at other "newer" universities, see, e.g., CharTer (SECOND SCHEdule) $\S 9$, in STIRLING CALENDAR, supra note 41, at 74-77; CHARTER (SCHEDULE) $\S 9$, in DUNDEE CALENDAR, supra note 41, at 158-59; CHARTER OF HERIOT-WATT UNIVERSITY (SCHEDULE), STATUTE XII, § 1 .

The newer universities may apply a formula to the membership of their governing boards, for example requiring a certain number of industrialists. Interview with Ellis John Powell, Regent, Univ. of Aberdeen, in Aberdeen, Scot. (Aug. 1, 1996) [hereinafter Powell Interview].

48. At the University of Michigan, the only campus person specified by law for the governing board is the President, who has no vote. See MiCH. ConsT. art. VIII, § 5. (The same holds true for Michigan State University and Wayne State University. Id.) Indeed, students may be ineligible to stand for election to the Michigan board, even as members of the general public. 4679 Op. Mich. Att'y Gen. 98 (1968) (since student has contractual relationship with University, service on governing board would constitute conflict of interest). At Indiana University only one student-and no member of the administration, faculty or staff-is legally specified for service on the board. IND. CODE ANN. $\$ 20-12-24-3.5$ (West 1995).

49. The President of the University of Michigan presides over the board of regents, though without a vote. MICH. ConST. art. VIII, $\S 5$. The formal distribution of power between the regents and the President at the University of Michigan seems anything but clear: The President (and the respective faculties) exercise the "immediate government of the several departments," but the regents have the power to "regulate the course of instruction, and prescribe, under the advice of the professorships, the books . . . to be used . . . and also to confer . . . degrees . . . and diplomas . . . ." Mich. COMP. LAws ANN. $\$ 390.11$ (West 1995).

50. Powell, supra note $35, \S 2.1$. 
campus events and to provide the relatively "hands-on" governance demanded of a Court. As one commentator put it, "it was essential that academics should be the largest single group, with enormous influence beyond its own numbers, on the Court, the body charged with managing and distributing resources and employing staff." 51 The typical presence on the Courts of Scottish universities of a heavy component of people from the campus and from the academic life of the university would strike most American observers as strange, indeed. The trustees of public colleges and universities in the United States tend either to be appointed by the Governor or by the Governor and legislative leaders, or to be elected by popular vote. ${ }^{52}$ At the University of Michigan, the general public elects all voting members of the governing board. ${ }^{53}$ At Indiana University, the Governor appoints six members and the alumni elect the other three..$^{54}$ At private universities in the United States, new trustees are chosen by sitting trustees. These members often try to "clone" themselves, choosing people with "the same educational, business or social background" and people who are "wealthy or have access to affluent potential donors." 55

The heavy campus representation within Scottish Courts makes it more difficult for the chief executive officer of the university (the Principal) to control the flow of information to the board and, consequently, its agenda, as often happens, at least absent some crisis, in American universities. ${ }^{56}$ Stories abound of trustees at American universities remaining unaware of crucial academic issues on campus. ${ }^{57}$ In one instance, members of a board

51. T.B. Skinner, University Government: A Comment, in ABERDEEN UNIVERSITY 1945-81: Regional Roles AND NATIONAL NeEDS 104 (John D. Hargreaves \& Angela Forbes eds., 1989).

52. Roberta P. Haro, Choosing Trustees Who Care about Things that Matter, CHRON. OF Higher EDUC., Dec. 8, 1995, at B1. At the University of Michigan, Michigan State University and Wayne State University, for example, the State Governor makes appointments to fill vacancies on the governing board, but those appointed serve only until an election can be held. MiCH. CoNST. art. VIII, §5. The Governor of Michigan has recommended the termination of all direct election of trustees in favor of gubernatorial appointments. Patrick Healy, Mich. Governor Would End Direct Election of Trustees, CHRON. OF HIGHER EDUC., Oct. 20, 1995, at A30.

53. MICH. CONST. art. VIII, $\$ 5$. Michigan is "one of four states in which voters elect members of university boards . ..." Ways \& Means, CHrON. Of Higher EduC., Nov. 15 , 1996, at A35.

54. IND. CODE ANN. \$§ 20-12-24-2, -3, -5 (West 1995).

55. Haro, supra note 52, at B1.

56. The board of trustees at the University of West Virginia, for example, vetoed a plan providing benefits to partners of homosexual and other unmarried employees. The administration had earlier adopted the plan but suspended it due to the concern of the trustees. Chron. Of Higher Educ., Nov. 17, 1995, at A23.

57. This is not to say that all close management by such boards is precluded. The regents of the University of Michigan have the formal power to choose the "books and authorities" used in instruction, MICH. COMP. LAWS ANN. $\$ 390.11$ (West 1995), although 
of trustees first learned from the public media that the institution had ceased using the Scholastic Aptitude Test to screen student admissions; later the President informed one board member who questioned the change that the issue was not "a board matter." 58 Unsurprisingly, some have bemoaned American trustees' preoccupation with "issues related to money, institutional prestige, and presidential searches, rather than issues involving academic quality or educational access." ${ }^{99}$ Indeed, trustees often see their duties as limited to raising funds and supporting the administration. ${ }^{60}$

There are some indications that the willingness of trustees of American universities to become more aggressively involved in the life of the university has increased, thus inevitably reducing the control of the President. ${ }^{61}$ As one trustee of a public university recently wrote, "[m]any trustees have ceded too much of their statutory authority for overseeing public higher education to campus presidents and faculty councils." 62 To some, the status of "outsider" presents not a disadvantage, but the distinct plus of neutrality and accountability to the public. ${ }^{63}$

Today, the Scottish university Court is a "body corporate" with both a common seal and the power of perpetual succession. It administers the property and revenues of the university, provides review of any decision of the Senate, receives reports from the Senate and the General Council, makes appointments, fixes fees, and, on the recommendation of the Senate, prescribes regulations for academic courses of study.$^{64}$ University Courts, however, do not exercise unbridled power. Often their authority, while the ultimate one, gets exercised only as the result of an initiative at a lower level. For example, the Court may have the authorization to make appointments to the academic staff, but only those initiated by the Senate..$^{65}$ In a very real

one trusts that the board does not often exercise that power. There are some signs that boards are becoming increasingly active. See U. of Mass. Trustees Reject Tenure for 3 Professors, CHRON. OF HighER EdUC., Sept. 8, 1995, at A27: "[B]eing recommended for tenure by the president no longer means that approval by the Board . . . is a fait accompli." See also "State Notes," id. at A52.

58. Candace de Russy, Public Universities Need Rigorous Oversight by "Activist" Trustees, CHRON. OF HigHER EDUC., Oct. 11, 1966, at B4.

59. Haro, supra note 52.

60. de Russy, supra note 58.

61. See, e.g., U. of Nebraska Regents Overturn Tenure Denial, CHRON. OF HigheR EDUC., Nov. 8, 1996, at A13; and Patrick Healy, Activist Republican Trustees Change the Way Public Universities Seek Presidents, CHRON. OF HIGHER EDUC., Aug. 9, 1996, at A19. ("With the advent of tough-minded managers and Republican activists on governing boards, public-university leaders often must choose between swallowing controversial policies made by devoted ideologues or risk losing their jobs." Id.)

62. de Russy, supra note 58, at B3.

63. Id.

64. ABERDEEn Calendar, supra note 47, at 9.

65. At the University of Aberdeen, during the middle of this century, "the Court itself 
sense, the Court has the power of the purse, ${ }^{66}$ and this power drives the others. Also in a very real sense, the Court is the last, and supreme, source of authority before any recourse to the civil courts. As a result, although university Courts may come down on one side of an issue, they may eschew "siding" with one faction within the university; surely they will hesitate to initiate tension within the university. ${ }^{67}$

\section{The University Senate ${ }^{68}$}

Until the university Courts were created in the nineteenth century, the Senatus Academicus, or the Senate, remained the ultimate power at the four universities then in existence. ${ }^{69}$ Even today, however, the Senate, sometimes called the "supreme academic body," 70 exerts formidable authority over Scottish universities, driving both in theory and in fact a dramatic part of the academic life of the institution. Regardless of the "constitutional niceties," the Senate controls the university's academic affairs insofar as they can be separated from issues of resources. ${ }^{71}$ At the University of Aberdeen, for example, "[t]he Senate is charged with the regulation and superintendence of the teaching and discipline of the University, and with the promotion of research." 72 Moreover, no degree may be conferred except upon the authority of the Senate. ${ }^{73}$ At the University of Stirling, the Senate parallel

was still active in making appointments. . . At some point custom changed, and by the late 1960 s it was well established practice for the Court simply to accept the recommendations of appointing committees." Jennifer Carter, Structures and Processes of Internal Government, in ABERDEEN UNIVERSITY 1945-81: REgIONAL ROLES AND NATIONAL NEEDS, supra note 51, at 102 .

66. Interview with Peter Clark, Proctor, and Frank Quinault, Hebdomadar, Univ. of St. Andrews, in St. Andrews, Scot. (July 18, 1996) [hereinafter Clark \& Quinault Interview].

67. Powell Interview, supra note 47.

68. The nomenclature among Scottish universities is not inevitably uniform; at the University of Stirling, for example, the Academic Council serves as the parallel to the Senate at other universities. See, e.g., CHARTER § 9(1), in STIRLING CALENDAR , supra note 41, at 64.

69. See supra text accompanying notes 10-14. Conflict between groups on campus, however, predated the development of the Court. At the University of Glasgow, the Principal and the holders of the thirteen chairs created prior to 1761 deemed themselves alone to be "the Faculty;" they further maintained that the "new Professors," though holders of "Regius" Chairs, were merely members of the Senate with no say in the administration of the "College" and especially its revenues. The 1858 legislation, see supra text accompanying notes 34-37, even as it created the Court and the General Council, dissolved the distinction between the Senate and the Faculty. UNIVERSITY OF GLASGOW, HISTORY AND CONSTITUTION vii (1977) [hereinafter GLASGOW HISTORY].

70. UNIVERSITY OF ST. ANDREWS, PROSPECTUS 1996 ENTRY, at 6 (1996).

71. FARRINGTON, supra note 17 , at 182.

72. ABERDEen Calendar, supra note 47 , at 9.

73. Id. 
(called the "Academic Council") "acts as the authoritative body for purely academic matters . . . "74 To be sure, the Court, formally at the top of the power list, controls the purse and thus may preclude virtually any exercise of power on the part of the Senate. Nonetheless, the latter, by virtue of its academic prerogatives-including its exclusive power to initiate some changes on campus ${ }^{75}$ and its right at least to be consulted about others $^{76}$ - exercises fairly exclusive control over the academic aspects of the university. ${ }^{77}$

Despite these general points, the relationship between the Court and the Senate at Scottish universities varies. In the four ancient universities and in the post-1992 universities, the Courts retain considerable formal and direct control over the Senates' actions; in fact, in the newer universities, the Court appoints the members of the Senate. In the four chartered institutions, the powers of the Courts are set out separately from those of the Senate. In these institutions, the Court's power over the Senate is indirect, but real: The Court may withhold the resources necessary to any undertaking of the Senate. $^{78}$

74. STIRLING HANDBOOK, supra note 12, at 3. For the powers of the Senates at the four ancient universities, see THE UNIVERSITIES (SCOTLAND) ACT 1889, $\S 7$; and THE UNIVERSITIES (SCOTLAND) ACT 1966, § 8. For the powers of the Senates (or parallel body) at other universities, see e.g. . CHARTER $\S 9(1)$, in STIRLING CALENDAR, supra note 41, at 64 ("responsible for the academic work of the University, both in teaching and in research, and for the regulation and superintendence of the education, discipline and welfare of the students . . . "); STATUTE 10, \& 4, in STIRLING CALENDAR, supra note 41, at 77; CHARTER OF HERIOT-WATT UNIVERSITY \$ 9(1) ("responsible for the academic work of the University, both in teaching and in research, and for the regulation and superintendence of the education and discipline of the students . . . "); CHARTER OF HERIOT-WATT UNIVERSITY (SCHEDULE), STATUTE XIII, § 4. See also CHARTER § 8(1), in DUNDEE CALENDAR, supra note 41, at 150; and CHARTER (SCHEDULE), STATUTE 10, $\$$, in DUNDEE CALENDAR, supra note 41 , at 164.

75. For an example of the extent to which a Court might be limited by the Senate's exclusive power to initiate-or at least to approve-certain actions, including academic appointments, see CHARTER OF HERIOT-WATT UNIVERSITY (SCHEDULE), STATUTE XII, § 8(b), (c), and (d); CHARTER OF HERIOT-WATT UNIVERSITY § 22(2); CHARTER OF HERIOT-WATT

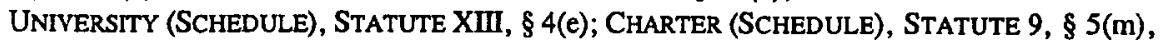
in DUNDEE CALENDAR, supra note 41 , at 162.

At the University of Dundee, the Senate recommends persons for appointment to the academic staff only when requested by the Court. CHARTER (SCHEDULE), STATUTE 10, $\S$ 5(I)(iii), in DUNDEE CALENDAR, supra note 41, at 164. at 152 .

76. See, e.g., ChaRTER $\S 16(3), 17(2), 19(1)$, in DundeE Calendar, supra note 41 ,

77. See, e.g., Charter $\S 22(2)$, in STIRLIng CALENDaR, supra note 41 , at 66 (the Court may not by ordinance deal with such matters as courses of study, diplomas, degrees, academic distinctions, and examinations, except on the recommendation or concurrence of the Academic Council-the Senate parallel at the University of Stirling). See also CHARTER $\S$ 9(1), in DUNDEE CALENDAR, supra note 41 , at 150.

78. FARRINGTON, supra note 17 , at 177. 
The relationship between the two bodies may be tightened but also complicated by membership common to both bodies. At the University of Aberdeen, for example, the Principal and three Vice-Principals sit on both bodies. Moreover, the Court also includes six assessors elected by the Senate from among its own membership. ${ }^{79}$ Thus, at least ten individuals serve on both bodies; ${ }^{80}$ one can only speculate as to how the loyalties of these members line up.

The complementary powers and reciprocal relationship of these two bodies promote a mutual check on each other's exercise of authority. For example, the Senate's academic expertise may be protected through its exclusive power to recommend the appointment of a member of the academic staff; ${ }^{81}$ conversely, however, the Court may limit the nature and number of these appointments through its funding power.

Despite the advantages of complementary powers, problems have arisen due to the interplay between Courts and Senates. A fairly close working relationship becomes of paramount importance when, in effect, each of the two bodies can stymie the other. Moreover, planning becomes very difficult for any body wholly dependent upon another for effectiveness. Not long ago, at the University of Aberdeen, "academic objectives were prioritized by faculties and Senatus, and costed by Court, but there were only fitful attempts to link Court and Senatus in a central planning process." 82 From the 1940 s to the 1980 s, the University reportedly remained excessively centralized, with the Court holding the crucial powers over finance, external relations, and appointments. The Court, consistent with governing law, looked to the Senate to give shape to the University, but until the early 1980s, the Senate "lacked full knowledge of financial matters and external circumstances" and was "too incoherent a body itself to" contribute effectively to the planning process. ${ }^{83}$

Committees to serve as a liaison have developed to promote the smoother operation-including the planning-of this tandem. At the University of St. Andrews, for example, the Planning and Resources Committee (PARC) works to bridge the inevitable gap between the controller

79. ABERDEEN CALENDAR, supra note 47, at 8-9. "It could indeed be argued that the Senatus Assessors on the Court, while they are there as Assessors not Representatives, have a weighty responsibility for the academic policy and discipline of the University, and for putting forward the views of the Senate even when those views are not their own." Powell, supra note $35, \S 3.6(5)$.

80. At the University of Edinburgh, the Principal sits on both the Court and the Senate. The Court also includes four Senate assessors, bringing to at least five the membership common to both groups. See Edinburgh Calendar, supra note 40, at A-6 to A-7. $8(c)$.

81. See, e.g., CHARTER OF HERIOT-WATT UNIVERSITY (SCHEDULE), STATUTE XII, $\S$

82. Carter, supra note 65 , at 97.

83. Id. See also Skinner, supra note 51, at 131. 
of the purse, on the one hand, and the highest academic body in the institution, on the other. ${ }^{84}$

While campus personnel find themselves well represented on university Courts ${ }^{85}$ only such personnel populate the Senates. ${ }^{86}$ As such, what has been said about academic, internal influence within university Courts-as compared with boards of trustees in the United States-echoes many times more loudly with regard to the Senates. At the University of Aberdeen, for example, the Senate comprises the Principal; the Vice-Principals; established (chaired) professors and Heads of Department, together with-if not otherwise members-the Deans of the Faculties and Conveners of the Boards of Studies; the Librarian; the Convener of the Committee of Wardens of Halls of Residence; the Director of the University Computing Center; elected personal (non-chaired) professors, readers, and lecturers (who must number no fewer than one-half the number of ex officio members); the Principals (or their nominees) of the colleges whose degrees the university validates; and nine student members. ${ }^{87}$ This list yields an enormous body that includes more than 165 members when all chairs are occupied ${ }^{88}-$ a common, though not inevitable, situation in Scottish universities. ${ }^{89}$ The Principal of the university typically presides over the Senate. ${ }^{90}$ Despite its many and important responsibilities, the university Senate may not meet all that often; at the University of Edinburgh, the Senate meets six times a year. ${ }^{91}$

84. Clark \& Quinault Interview, supra note 66.

85. See supra text accompanying notes $42-51$.

86. As envisaged in the 1858 legislation reorganizing Scottish universities, the Senates were composed solely of the Principal (or Principals) and the "whole professors." THE UNIVERSITIES (SCOTLAND) ACT 1858, § 5.

87. ABERDEEN CALENDAR, supra note 47, at 9. See also UNIVERSITY OF ABERDEEN, ORdinanCE No. 122 (AMENDMENT OF THE COMPOSITION OF THE SENATUS ACADEMICUS) (1980). Senate assessors to the University Court who are not otherwise members of the Senate may attend Senate meetings. ABERDEEN CALENDAR, supra note 47, at 9.

88. See ABERDEEN CALENDAR, supra note 47, at ix-xvi.

89. See, e.g., ST. ANDREWS CALENDAR, supra note 47, at 2.4-2.7 (110 members); EDINBURGH CALENDAR, supra note 40, at A-7 through A-9 (over 300 members). See also SCHEdUle, STATUTE $8, \S 1$ and ChaRTER, STATUTE $10, \S 1$, in DundeE CalendaR, supra note 41, at 160. The Academic Council (the Senate parallel) at the University of Stirling is much smaller, with well under thirty members. See STATUTE $10, \S 1$, in STIRLING CALENDAR, supra note 41 , at 77.

90. See, e.g., ST. ANDREWS CALENDAR, supra note 47, at 2.4; ABERDEEN CALENDAR, supra note 47, at 9; EDINBURGH CALENDAR, supra note 40, at A-24; STATUTE 10, § 3, in STIRLING CALENDAR, supra note 41 , at 77; and CHARTER (SCHEDULE), STATUTE 10, $\$$ 3(a), in DUNDEE CALENDAR, supra note 41 , at 164 .

91. Edinburgh CALENDAR, supra note 40, at A-24. 


\section{The General Council}

Since $1858,{ }^{92}$ Scottish universities have included in their hierarchy of governance a large,$^{93}$ unwieldy group, usually called the General Council, made up of virtually everyone who has ever had contact with the university. The General Council at the University of Aberdeen, for example, includes: 1) all graduates of the University, 2) the Chancellor of the University during his tenure, 3) all present and past professors and members of the University Court, 4) all readers and lecturers who have held office in the University for more than a year, and 5) all former readers and lecturers who have remained part of the University staff until retirement. ${ }^{94}$ Understandably, and perhaps fortunately, not all show up for meetings; as one commentator noted, the Council, at least during part of its history, has consisted "in theory of all graduates, and in practice of professional men in Aberdeen who had the time and interest to attend its meetings." 95 The Council holds two statutory meetings annually and may hold special meetings as prescribed by its rules. ${ }^{96}$

These bodies were intended to involve graduates formally in the universities' business and to increase the universities' public accountability. ${ }^{97}$ Although the General Council may exercise considerable moral suasion, its formal powers, despite enlargement under the Universities (Scotland) Act of 1889 , remain limited, indeed. In a very real sense, its major impact comes not through its own deliberations, but through its impact on the deliberations of the University Court, to which the Council elects four assessors. The Council also elects the Chancellor, the titular head of the university and the President of the Council. ${ }^{98}$ At one time, interestingly, the General Councils of the four "ancients" jointly returned three representatives to Parliament. The Representation of the People Act of 1948, however, abolished university constituencies. ${ }^{99}$

92. See GlasGow HISTORY, supra note 69, at vii. The Universities (Scotland) Act of 1858 established two new bodies: The University Court and the General Council. Id.

93. At the University of Edinburgh, as of May 1995, the General Council had 93,884 members. EDINBURGH CALENDAR, supra note 40, at A-23.

94. Notes on the Constitution of the University, in ABERDEEN CALENDAR, supra note 47, at 7, 9. The memberships of the Councils at the University of Glasgow and at the University of Edinburgh reflect this arrangement. See GLASGOW HISTORY, supra note 69, at ix; EDINBURGH CALENDAR, supra note 40, at A-7, A-23.

95. R. D. ANDERSON, THE STUdENT COMMUNITY AT ABERDEEN: 1860-1939, at 27 (1988).

96. Notes on the Constitution of the University, in ABERDEEN CALENDAR, supra note 47, at 7, 9. The same situation prevails at the University of Glasgow. See GLASGOW HISTORY, supra note 69, at X. See also EDINBURGH CALENDAR, supra note 40, at A-24.

97. Powell, supra note $35, \S 2.2$.

98. Notes on the Constitution of the University, in ABERDEEN CALENDAR, supra note 47, at 7-9. For more on the Chancellor, see infra text accompanying notes 108-18.

99. GlasGow HistoRY, supra note 69 , at $\mathrm{X}$. 
The Council may consider any question affecting the "well-being and prosperity" of the university. ${ }^{100}$ During the late nineteenth century, discontent with Aberdeen's curriculum found expression primarily through the Council. ${ }^{101}$ The Council, however, has no dispositive power regarding such issues; it may only "make representations" to the University Court concerning these matters, and thus force the Court to consider them and "return to the Council their deliverance thereon." 102 Finally, the University Court must present to the Council each year a report on the work of the university and an audited financial statement. ${ }^{103}$

\section{Other Bodies}

Faculties, schools, departments, and Boards of Studies-in no predictable pattern-round out the groups forming part of the hierarchy in Scottish universities. ${ }^{104}$ The University of Aberdeen boasts four faculties: Arts and Divinity, Medicine and Medical Sciences, Science and Engineering, and Social Sciences and Law. ${ }^{105}$ The University deploys six Boards of Study: Arts and Social Sciences, Science, Engineering, Divinity, Law, and Medicine. ${ }^{106}$

100. The UNIVERSITIES (SCOTLAND) ACT $1858, \S 6$.

101. ANDERSON, supra note 95, at 27.

102. THE UNIVERSITIES (SCOTLAND) ACT $1858, \S 6$.

103. The UNIVERSITIES (SCOTLAND) ACT 1966, $\$ 12(1)$. For more on the role of the General Council at other universities, see GLASGOW HISTORY, supra note 69 , at vii, ix-x; History and Constitution, in EDINBURGH CALENDAR, supra note 40, at A-23. Heriot-Watt University has a General Convocation, see CHARTER OF HERIOT-WATT UNIVERSITY § 7, and (SCHEDUle), STATUTE XI; and an Academic Congress, see ChaRTER OF HERIOT-WATT UNIVERSITY § 13 and (SCHEDULE), STATUTE XVIII. The University of Dundee has a Graduates' Council, see CHARTER $\S 12(1)$, in DUNDEE CALENDAR, supra note 41 , at 151 ; and SCHEDULE $\$ 20$, in DUNDEE CALENDAR, supra note 41, at 184; and an Academic Council, see id. at 185; see also CHARTER $\S 13(1)$, in DUNDEE CALENDAR, supra note 41, at 150; SCHEDULE $\S 15$, in DUNDEE CALENDAR, supra note 41 , at 168 . The University of Stirling has a Conference, see CHARTER $\S 7$, in STIRLING CALENDAR, supra note 41 , at 4; STATUTE 8 , in STIRLING CALENDAR, supra note 41 , at 71 . The University of Stirling also has an Academic Assembly and a Staff Assembly. See StatuTes 13 \& 14, in STIRLING CaLENDAR, supra note 41 , at 81 .

104. FARRINGTON, supra note 17 , at 183.

105. Each Faculty has an Advisory Committee, a Planning Committee, and an Academic Board. Notes on the Constitution of the University, in ABERDEEN CALENDAR, supra note 47, at 7,10 .

106. Id. Each Board of Study is comprised of all heads of department, plus representatives of both faculty and student body. The Senate delineates the responsibilities of each Board of Study. Id. 


\section{B. The Major Officers}

\section{General}

The Chancellor, the Principal and the Rector-three very different positions-sit atop the hierarchy of individuals at Scottish universities. Parliamentary legislation has remained "curiously silent" about these major offices, a silence that may account for their survival into the twentieth century. ${ }^{107}$

\section{The Chancellor}

The Universities (Scotland) Act of 1858 provided for a Chancellor at each of the ancient universities. Under the legislation, the Chancellor, elected by the "other" members of the General Council, ${ }^{108}$ holds office for life. The Chancellor has power to confer degrees and to appoint a ViceChancellor ${ }^{109}$ for that purpose only! ${ }^{10}$ The Chancellor presides over meetings of the General Council and, at those meetings, exercises both a deliberative and a casting vote. ${ }^{11}$ Despite these relatively meager duties, the

107. Powell, supra note $35, \S 3.60$.

108. For details on this election at the University of Aberdeen, see ORDINANCE No. 123, in UNIVERSITY OF ABERDEEN, THE ACTS, ORDINANCES AND RESOL UTIONS AFFECTING THE UNIVERSITY OF ABERDEEN: 1858-1990, at 115 (1991) [hereinafter ABERDEEN ACTS, ORDINANCES \& RESOLUTIONS]. The Senatus Academicus formerly elected the Chancellor, but the Universities (Scotland) Act of 1858 transferred the power to the newly created General Council. Powell, supra note $35, \S 1.2$.

109. The office of Vice-Chancellor today commonly falls to the Principal. See, e.g., Notes on the Constitution of the University, in ABERDEEN CALENDAR, supra note 47, at 8; GLASGOW HISTORY, supra note 69, at Xii; STIRLING HANDBOOK, supra note 12, at 5.

110. THE UNIVERSITIES (SCOTLAND) ACT 1858, § 2.

111. Id. § 6. For descriptions of the office at particular universities, see, e.g., Notes on the Constitution of the University, in ABERDEEN CALENDAR, supra note 47, at 8; GLASGOW HISTORY, supra note 69, at xii; History and Constitution, in EDINBURGH CALENDAR, supra note 40, at A-22; CHARTER OF HERIOT-WATT UNIVERSITY \& 4; CHARTER OF HERIOT-WATT UNIVERSITY (SCHEDULE), STATUTE III; CHARTER \$ 4, in DUNDEE CALENDAR, supra note 41, at 149, and Schedule, STATUTE 3, in DUNDEe CalendaR, supra note 41, at 155; STIRLING HANDBOOK, supra note 12 , at 5 .

At Heriot-Watt University, the Chancellor presides over the General Convocation and holds office for seven years. The Convocation appoints the Chancellor on the nomination of the Court and the Senate sitting in joint session. See CHARTER OF HERIOT-WATT UNIVERSITY $\S \S 4(1)$ and (3) and (SCHEDULE), STATUTE III. At the University of Dundee, the Chancellor, appointed by the Court, presides over the Graduates' Council. CHARTER $\$ 4(1)$, in DUNDEE CALENDAR, supra note 41, at 149; and SCHEDULE, STATUTE 3, in DUNDEE CALENDAR, supra note 41 , at 155 . At the University of Stirling, the Chancellor presides over the Conference, STIRLING HANDBOOK, supra note 12 , at 5 , and holds office for seven years, STATUTE 4 , $\S$ 1 , in STIRLING CALENDAR, supra note 41 , at 71. 
Chancellor is the titular head of the university. ${ }^{112}$ This sharp contrast between appellation and power seems best captured by the description of the office set out in a "Handbook for Students" at the University of Stirling: "The Chancellor is Head of the University, but has no direct powers ...."113 The Chancellor, therefore, exercises some of the ceremonial duties of the American university President, who combines the functions of both Scotland's Chancellor and Principal. One can see in the ChancellorPrincipal arrangement some echo of the United Kingdom's Monarch-Prime Minister arrangement.

Despite the current lag between title and formal power, some early Chancellors exerted enormous influence over their institutions. Bishop Elphinstone, the founder of the University of Aberdeen, exercised as Chancellor a "uniquely powerful" position. He not only selected the entire teaching staff and the student body, but also determined the structure of the institution's constitution, though with some required advice. In this respect, his influence loomed larger than that of his fellow Chancellors at the Universities of St. Andrews and Glasgow. In imparting upon the University its basic structure and direction, however, he clearly intended no such overall control for his successors; the University's most important offices were thereafter to be elective. This said, he saw the Chancellor's role not as merely honorific, but as one demanding "active leadership, vigilance and prudence."114

Despite the power exercised by Elphinstone, the Chancellor has almost always been a university "outsider." At one of the University of Aberdeen's predecessor institutions, King's College, the Bishop of Aberdeen served as Chancellor for two centuries. ${ }^{115}$ From the eighteenth century, a Scottish nobleman usually held the office; more lately still, a "public man from the worlds of politics or administration" has exercised the role. Defending the university and often serving as a link between the institution and royal or central government, the Chancellor exercised "visitorial" powers over the university, powers the position might still carry. ${ }^{116}$ The selection of a Chancellor often reflects more glory on the University than on the person selected: The first Chancellor at the University of Dundee was "Our most

112. See, e.g., Notes on the Constitution of the University, in ABERDEEN CALENDAR, supra note 47, at 9; GLASGOW HISTORY, supra note 69, at xii.

113. STIRLING HANDBOOK, supra note 12 , at 5.

114. LESLIE J. MACFARLANE, WILLIAM ELPHINSTONE AND THE KINGDOM OF SCOTLAND 1431-1514: THE STRUGGLE FOR ORDER 348 (1995).

115. Powell, supra note $35, \S 1.2$. At the University of Glasgow, similarly, the office was held by Bishops and Archbishops of Glasgow until the Reformation and thereafter during the establishment of the episcopacy. GLASGOW HISTORY, supra note 69, at xii.

116. Powell, supra note 35, §1.2. 
dearly beloved Mother, Queen Elizabeth, the Queen Mother";117 at the University of Edinburgh, the Chancellor is His Royal Highness Prince Philip, Duke of Edinburgh. ${ }^{118}$

\section{The Principal}

In Scotland the Principal, paralleling the university President in the United States and the Vice-Chancellor ${ }^{119}$ in England and Australia, operates as the chief executive officer of the University. At the University of Aberdeen, for example, the Principal serves as both the resident head and the president of the Senate. Moreover, the position of Principal carries with it membership on the Court, the main policy-making body of the University, and on the General Council, over which the Principal also presides in the absence of the Chancellor and the Rector. ${ }^{120}$ Why does the Principal, who has always been the person "in day-to-day charge of the university," 121 chair the Senate ${ }^{122}$ but not the Court? This seems best explained by the fact that the Senate, until the creation of university Courts in 1858 , constituted the governing body of the university. ${ }^{123}$ The importance of the Principal even

117. ChARTER $\S 4(2)$, in DUNDEe CalendaR, supra note 41 , at 149.

118. See EdINBURGH CALENDAR, supra note 40, at A-5.

119. At Scottish universities, the Principal is also commonly Vice-Chancellor, see, e.g., Notes on the Constitution of the University, in ABERDEEN CALENDAR, supra note 47, at 8; CHARTER § 5.1, in STIRLING CALENDAR, supra note 41, at 64; CHARTER OF HERIOT-WATT UNIVERSITY § 5(1); and CHARTER, $\S 6(1)$ (a), in DUNDEE CALENDAR, supra note 41 , at 150 , but as Vice-Chancellor exercises extremely limited powers; legislation in 1858 limited the Vice-Chancellor to conferring degrees, and then only in the absence of the Chancellor. See Powell, supra note 35, § 1.3; and THE UNIVERSITIES (SCOTLAND) ACT 1858, § 2.

120. Notes on the Constitution of the University, in ABERDEEN CALENDAR, supra note 47, at 8. Other universities follow suit; see, e.g., UNIVERSITY OF GLASGOW, CALENDAR 68788 (1995-96) [hereinafter GLASGOW CALENDAR] (Principal serves on University, Court and chairs Senate); and, to the same effect, EDINBURGH CALENDAR, supra note 40, at A-6, A-7, and History and Constitution, in EDINBURGH CALENDAR, supra note 40, at A-23. For the Principal's duties at other universities, see CHARTER $\$ 5.1$, in STIRLING CALENDAR, supra note 41, at 64 (chief academic and administrative officer); CHARTER $\S 6(1)(a)$, in DUNDEE CALENDAR, supra note 41, at 150 (chief academic and administrative officer); and CHARTER OF HERIOT-WATT UNIVERSITY $\S 5(1)$ (chief academic and administrative officer).

121. Powell, supra note 35, § 1.3. At the University of Aberdeen, "by 1514 the overriding responsibility for the efficient day to day running of the University, in all its administrative, academic and disciplinary aspects, rested with the Principal . . . ." MACFARLANE, supra note 114 , at 356 . Until the current century, the Principal at Aberdeen was required to teach, as well as govern. Powell, supra note $35, \S 1.3$.

122. At the ancient universities, eighteenth-century legislation made the Principal the President of the Senate and allocated to the position both "a deliberative and a casting vote." See THE UNIVERSITIES (SCOTLAND) ACT 1858, \& 5.

123. Powell, supra note $35, \S 1.3$. 
since that time, however, becomes starkly apparent in one account of Aberdeen's recent history:

The Principal, as head of the "Establishment[,]" had an increasingly hard job in this period [1945-81], not only with a mounting workload within the university, but with ever increasing demands for external contacts, especially with the UGC and CVCP. . . . [I]t remained true throughout the period that the principal was the single most important person in the university. He bridged crucial areas-internal-external affairs, Court-Senatus relations, and the connection of academics with administrators. . . . In a list of 69 committees, most [were] chaired by the principal . . . ${ }^{124}$

\section{The Rector}

Five of Scotland's universities list, among their very top officers, a Rector. ${ }^{125}$ If, to an American, the Visitor occupies the oddest university position in Australia ${ }^{126}$ or England, ${ }^{127}$ surely, to that same American, the Rector occupies that position in Scotland. The Universities (Scotland) Act of 1858 provided that the Rector should preside over the newly created university Court-the institution's governing board-with both a deliberative and casting vote. ${ }^{128}$

124. Carter, supra note 65, at 101. Not much has changed for the university Principal; at the University of Stirling, for example, the Principal is an ex-officio member of every Committee or Joint Committee of the Court (except the Audit Committee) and of the Academic Council (Stirling's equivalent of the Senate). CHARTER (SECOND SCHEDULE), STATUTE 12, §\$ 3-4, in STIRLING CALENDAR, supra note 41 , at 80.

125. Henderson \& Mattison, supra note 14 , at 22 . The other seven universities and the other higher-education institutions have no Rector. The University of Stirling does have a parallel, the Honorary President of the Students' Association, who serves as a full member of the University Court. FARRINGTON, supra note 17, at 220. Heriot-Watt University also has no Rector but does have the Honorary President of the Students' Association, who serves on the Court but does not chair it, Parkinson Interview, supra note 6.

126. See Dutile, supra note 4, at 78-84.

127. Scottish universities have no "Visitor" because that concept developed during the reign of Henry VIII in England, before Scotland "came on board." Farrington Interview, supra note 6.

128. The UNIVERSITIES (SCOTLAND) ACT 1858, § 4. This was continued in later legislation. See THE UNIVERSITIES (SCOTLAND) ACT 1889, § 5(5). Interestingly, the University of Dundee has the position of Rector, CHARTER $\$ 5$, in DUNDEE CALENDAR, supra note 41, at 155, but the Rector, though a member of the Court, is not ex officio its chair; the chair is elected by the Court from among certain of its members. CHARTER (SCHEDULE), STATUTE 9, in DUNDEE Calendar, supra note 41 , at 159 . The term is three years. ChARTER § 5(a), in DundeE CALENDAR, supra note 41, at 156. The University of Stirling has no Rector; the Court elects its chair from among those members who have no academic 
Though in its modern appearance the office of Rector dates only to the mid-nineteenth century, its history traces back to the beginning of universities in Scotland. At Aberdeen, for example, the Rector assumed executive functions early on in the University's history; ${ }^{129}$ the Chancellor, being a bishop, often found himself away from the institution and therefore in need of someone to preside over university business and represent corporate authority. Thus, the Rector carried the Chancellor's commission to oversee all university affairs and report annually to the Chancellor, who retained overriding responsibility. ${ }^{130}$ Originally charged with visitatorial powers and presiding over a rectorial court, ${ }^{131}$ the Rector heard grievances and addressed matters of discipline and administration.

Unlike their European parallels, however, the Scottish Rectors apparently "did not become the effective heads of their universities." 132 Although the Rector's current seniority falls somewhere between those of the Chancellor and the Principal, the Rector's function resembles more closely that of the former. ${ }^{133}$ The job falls upon outsiders today; relatively late legislation makes clear that no university employee, academic or otherwise, should occupy this position at any of the "ancients." 134 As well, students are barred from the office. ${ }^{135}$

The Rector in Scotland was always elected, sometimes by students exclusively and sometimes with staff participating. ${ }^{136}$ Indeed, the central role

appointment at the University. CharTER (SECOND SCHEDUle), in STIRLING CaLENDAR, supra note 41, at 80 . Heriot-Watt also has no Rector; the court there elects its chair from among "such of its members as are not members of the staff or students of the University . . . " Charter OF Heriot-WATt UNIVERSITY (SChEDUle), STATUTE XII, $\S$ 10(1).

129. The position of Rector appears in Aberdeen's Foundation Bull of 1495; the office of Principal gets no mention until 1505. MACFARLANE, supra note 114, at 349.

130. MACFARLANE, supra note 114, at 348-49.

131. Early Scottish Rectors held courts "to which students could be summoned to answer any civil or criminal charges ...." Id. at 351 .

132. Powell, supra note $35, \S 1.6$. But see Glasgow HISTORY, supra note 69 , at xiii, reporting that the Rector "was originally the active head of the University, exercising jurisdiction over all its members ...." For a thorough history of the early rectorship at Aberdeen, see MACFARLANE, supra note 114, at 348-56.

133. Powell, supra note $35, \S 1.4$.

134. THE UNIVERSITIES (SCOTLAND) ACT 1966, § 11(a) ("No person holding an appointment in any of the older Universities shall be eligible to be elected as rector of that University . . . ."). See also UNIVERSITY OF EDINBURGH, ORDINANCE OF THE UNIVERSITY COURT No. 180, § 6 (1977).

135. At the University of Edinburgh, for example, no student, full-time or part-time, may seek the rectorship. UNIVERSITY OF EDINBURGH, ORDINANCE OF THE UNIVERSITY COURT No. $180, \S \S 6,7$ (1977). The University of Dundee bars both staff and students from serving as Rector. Charter (SChedule), Statute 4, § 3, in Dundee Calendar, supra note 41, at 155 .

136. Powell, supra note $35, \S 1.5$. 
played by students in the election of the Rector would most surprise Americans. At the University of Aberdeen, for example, the Rector, who serves a three-year term, ${ }^{137}$ is elected by-and only by-the students. ${ }^{138}$ In other words, the person chairing the University's governing board takes that office not through the votes of the general public, or of other members of the Court, or even of the faculty; the students control the position-so too at St. Andrews, Glasgow, and Dundee. ${ }^{139}$ At the University of Edinburgh, which did not have the position until $1858,{ }^{140}$ the Rector is now elected by both "fully matriculated students" and staff members holding full-time appointments. ${ }^{141}$ Aberdeen has witnessed strong sentiments toward extending the rectorial electorate to the academic staff. ${ }^{142}$ Indeed, in the early 1970 s, some of the "ancients" thought the position should be changed from studentelected to Court-appointed, but the effort failed. ${ }^{143}$ Still, some continue to see the concept of Rector as incongruous with the modern framework of public accountability. ${ }^{144}$

Unsurprisingly, in view of the electorate, the Rector traditionally has represented the perspectives of the students, whether as a group or individually. ${ }^{145}$ Indeed, the sweeping university legislation of 1858 retained the office of Rector "as a safeguard of student interests." 146 The Student

137. UNIVERSITY OF ABERDEEN, ORDINANCE No. 115 (Election of Rector) $\S 4$ (1972).

138. Id. $\S 2 ;$ Notes on the Constinution of the University, in ABERDEEN CALENDAR, supra note 47 , at 8. The Senate sets out the regulations for the election. Id. For the election procedures, see UNIVERSTTY OF ABERDEEN, ORDINANCE NO. 115 (Election of Rector) (1972).

139. See UNIVERSITY OF ST. ANDREWS, PROSPECTUS 1996 ENTRY, at 6; GLASGOW HISTORY, supra note 69 , at xiii; and CHARTER $§ 5$, in DUNDEE CALENDAR, supra note 41 , at 149.

140. Powell, supra note $35, \S 1.5$.

141. UNIVERSITY OF EDINBURGH, ORDINANCE OF THE UNIVERSITY COURT No. $180, \S$ I (1977); History and Constitution, in EDINBURGH CALENDAR, supra note 40, at A-22. The Rector serves a three-year term. Id. For an example of the regulations under which a rectorial election takes place, see University of Edinburgh, Regulations for the Conduct of the Rectorial Election on Friday, 1st March, 1991.

142. See University Court of the University of Aberdeen, Working Party Anent the Rectorship, Final Report § C(1) [hereinafter Aberdeen Court Final Report].

143. Powell Interview, supra note 47. The government stated that it would not support the proposed change unless all four ancients agreed. On this issue, they did not-at least not at the same time. Id.

Controversy over the make-up of the rectorial electorate occurs early in Scotland's history. See, e.g., the eighteenth- and nineteenth-century conflict between students and professors at the University of Glasgow, recounted at GLASGOW HISTORY, supra note 69, at vi.

144. FARRINGTON, supra note 17, at 220.

145. Henderson \& Mattison, supra note 14 , at 22 . One historian of the position notes that the Rector came to be appointed by the students to defend their rights. Powell Interview, supra note 47.

146. COlLins ENCYClOPAEDIA OF SCOTLAND, supra note 11, at 347. 
Charter at the University of Aberdeen notes that the Rector "has a special responsibility to look after student interests." 147 This view of the position, however, has not been without doubt or disagreement. ${ }^{148}$ Nonetheless, unlike the Visitor in other countries and despite significant visitatorial powers in the office's ancient history, ${ }^{149}$ the Rector carries no legal power to settle disputes except through membership on the university Court. ${ }^{150}$ But as president of the Court-and appointer of others to the Court ${ }^{151}$-the Rector is clearly in a position to exert de facto power and, both within and without the Court, therefore, to be quite influential. ${ }^{152}$

The office presents a mixture of good and bad. Rectors can occasionally be troublesome. ${ }^{153}$ Moreover, students have not always taken the office, or the attendant elections and inaugurals, seriously. Occasionally students have used the election merely to make a political point. ${ }^{154}$ In one recent election at Glasgow, only eighteen percent of the students voted, despite the fact that the Rector serves as the students' voice at the Court. ${ }^{155}$ One account speaks derisively of Aberdeen's selection of "two media-men and an actor" during the 1970s. ${ }^{156}$ Another recounts the rowdiness attending the installation of various rectors. ${ }^{157}$ Of course, many Rectors

147. University of ABERdeEn, STUdent CharTer: Session 1995-96, at 5.

148. One document at the University of Aberdeen states that "the Rector does have responsibilities for the welfare of the university as a whole," even as it recognizes the "special connection between the Rector and the student body." Powell, supra note 35, §3.7(4). See also Aberdeen Court Final Report, supra note 142, § C(2) ("The Rector should at all times defend and advance the interests of the entire community of the University").

149. See MACFARLANE, supra note 114, at 350 (Rector at Aberdeen carried out annual visitations, "perhaps his most important task"). At Glasgow, the Rector "occasionally exercised visitatorial functions" until the eighteenth century. GLASGOW HISTORY, supra note 69 , at xiii.

150. Henderson \& Mattison, supra note 14, at 22.

151. See, e.g., History and Constitution, in EDINBURGH CALENDAR, supra note 40, at A22 (Rector appoints assessor to the Court).

152. Interview with Janet Rennie, Assistant Secretary, Univ. of Edinburgh, in Edinburgh, Scot. (July 19, 1996) [hereinafter Rennie Interview]; and Clark \& Quinault Interview, supra note 66 .

153. Rennie Interview, supra note 152.

154. Clark \& Quinault Interview, supra note 66.

155. Interview with Lawrence C. Reynolds, Assistant Clerk of Senate, Univ. of Glasgow, in Glasgow, Scot. (July 5, 1996) [hereinafter Reynolds Interview].

156. Colin McLaren, The Student Experience 1945-1978, in ABERDEEN UNIVERSITY 1945-1981: Regional Roles AND NATIONAL NEEDS, supra note 51, at 78.

157. See ANDERSON, supra note 95 , at 26-28, 30 (by the latter part of the eighteenth century, "there was a tradition of licensed disorder at rectorials"). The author tells of one installation at which:

[u]proar drowned all the proceedings, including the opening prayer . . . ; missiles were thrown, including dried peas, sticks, and broken pieces [of wood], and one splinter drew blood on [the new Rector's] face. The noisiest students were ejected, but they then threw stones through the windows and 
themselves- “"ornamental' Rector[s]"-have not taken the position seriously either, often attending few if any meetings of the Court. ${ }^{158}$ Even though the 1858 legislation made the Rector chair of the Court, until recently very few twentieth-century Rectors have chosen to so serve in practice, many remaining "virtual absentees." 159 Each of the ancients, at varying times, has moved for the separation of the rectorship from the Court's presidency, but the simultaneous unanimity indispensable for the required Act of Parliament continues to elude. ${ }^{160}$

Clearly the quality of service has varied greatly, and some Rectors have made little impact on their institutions. ${ }^{161}$ Rectors inevitably bring varying skills to the office, ${ }^{162}$ and the value of the rectorship depends, unsurprisingly, on the particular person elected ${ }^{163}$ This indictment stands although, or perhaps in some cases because, holders of the position have included famous persons ${ }^{164}$ such as Adam Smith and Benjamin Disraeli (at Glasgow), ${ }^{165}$ and T. H. Huxley (the students had wanted Charles Darwin, but he declined), Andrew Carnegie, and Winston Churchill (at Aberdeen). ${ }^{166}$ Although students sometimes expected politicians to be "working rectors,"167 national figures, in general, were unlikely to possess the detailed interest in university matters called for by the position. ${ }^{168}$ Toward the time of the Second World War, the rectorial fashion at Aberdeen turned to "theatre and media people." 169

Nonetheless, Rectors have played an important role at Scottish universities. ${ }^{170}$ At Aberdeen, following the legislation of 1858, several active

Id. at 26.

eventually stormed the hall again.

158. Id. at 26-28. See also Aberdeen Court Final Report, supra note 142, § C(5). See infra note 168 .

159. Powell, supra note $35, \S 3.4$.

160. Id.

161. See, e.g., Carter, supra note 65, at 101.

162. Reynolds Interview, supra note 155; and Rennie Interview, supra note 152.

163. Interview with Trevor Webb, Deputy Academic Registrar, Univ. of Aberdeen, in Aberdeen, Scot. (July 22, 1996) [hereinafter Webb Interview]; and Powell Interview, supra note 47 (Rector is as good or bad as the person in the position).

164. See ANDERSON, supra note 95, at 26 (noting famous Rectors who "appeared once to give an inaugural address but otherwise did nothing").

165. See UNIVERSITY OF GLASGOW, FACTS AND FIGURES (1995).

166. Powell, supra note $35, \S \S 3.1,3.2$. The earliest Rectors had been members of the aristocracy. Powell Interview, supra note 47.

167. Powell Interview, supra note 47. Politicians elected as Rector tended to come to their installation, chair the first meeting of the Court, then vacate the chair in favor of the Principal, perhaps never to attend a Court meeting again. Id.

168. Powell, supra note 35, §§ 3.1, 3.2.

169. Id. § 3.2 .

170. ANDERSON, supra note 95, at 26-30 (" $[$ T] $]$ he distinctive feature of Aberdeen in the 1870 s and 1880 s was the role of the rectorship in questions of university reform . . ."). 
Rectors attended Court proceedings faithfully and helped modernize the curriculum. There is some suggestion that the move towards less-active Rectors there followed the creation in 1884 of the Students' Representative Council, an organization that might have made the Rector's advocacy for students seem more superfluous. ${ }^{171}$ Still, some signs indicate that students have recently begun to take the office more seriously and to expect the Rector to show up at the Court and to represent the student view. ${ }^{172}$ Efforts are being made to increase the "commitment and consistency"-and therefore the effectiveness-of the Rector. ${ }^{173}$ It is still seen as important that the university's governing board be chaired by one directly elected from outside the university -and "thus susceptible to neither professional nor sectional pressure"174 and totally independent by law. ${ }^{175}$

Individual students have had recourse to the Rector in connection with individual conflicts with the university. ${ }^{176}$ But the Rector could play a much more important role in deflecting an increase in litigation against Scottish universities, just as a strengthened position of Visitor might at Australian universities. ${ }^{17}$ Especially as an "outsider," the Rector, over time, could establish a reputation as a fair, disinterested arbiter of disputes internal to the university. This could be brought about through legislation, agreement between the disputing parties-much like arbitration-or the accumulated perception of wisdom and persuasiveness, in the nature of an ombudsman. The benefits are obvious: more-informal, quicker, cheaper, less-divisive, and less-intrusive settlements of controversies. ${ }^{178}$

\section{INTERNAL PROCEDURES}

\section{A. Academic}

It is important to note that procedures for academic appeals at Scottish universities build upon a system of assessment that makes heavy use of

171. Powell, supra note $35, \S 3.2$.

172. This has been the case at St. Andrews, for example. Clark \& Quinault Interview, supra note 66. At Aberdeen, university officials will henceforth make it a point to remind both the students and the Rector of the position's responsibilities. Powell Interview, supra note 47.

173. See Aberdeen Court Final Report, supra note $142, \S \mathrm{C}(5)$.

174. See id. § B(2).

175. Powell Interview, supra note 47.

176. Clark \& Quinault Interview, supra note 66 . This apparently has not been the case at Aberdeen, however. Webb Interview, supra note 163.

177. See Dutile, supra note 4, at 83-84, 116.

178. Interestingly, one official commented that at Scottish universities the availability of the Rector obviated the need for either an ombudsman or a Visitor. Reynolds Interview, supra note 155 . 
external examiners, that is, examiners from other universities. ${ }^{179}$ Undoubtedly, these external assessments themselves provide a strong dosage of fairness to the academic process. Procedures for academic appeals at some Scottish universities are set out rather briefly. The University of Aberdeen, for example, spells out the process in less than two pages of text. ${ }^{180}$ The document, "Academic Appeals-Guidance Note," unselfconsciously states that "[n]o detailed rules about the conduct of an appeal are to be laid down, so that each individual appeal may be heard in the manner most appropriate to its particular facts and circumstances, and so that justice may be done, and may also be seen to be done."181

The document covers appeals against academic decisions rendered by heads of departments (including refusal to award certain certificates or to grant admission to a higher-level course); by examiners (including refusal to award "a pass," an award of an unacceptable "class of Honours," or failure to award Honours); or by a Committee appointed by the Senate to examine a thesis for a higher degree. (The document does not address academic dishonesty, which is, not atypically, ${ }^{182}$ treated under the University's disciplinary procedures.) ${ }^{183}$ Recognizing that "[s]pecific rights of appeal are very limited," the document nonetheless notes the Senate's authority over the teaching of the University and the Court's power to review any decision challenged by a member of the University. ${ }^{184}$

The Guidance Note requires that such appeals be lodged with the Academic Registrar within fourteen days of the challenged decision. ${ }^{185}$ The Guidance Note observes that student appeals lie first with the Senate.

179. FARRINGTON, supra note 17 , at 24 .

180. See also University of Strathclyde, Reg. 6.10 (Regulations Governing the Hearing of Student Appeals by the Appeals Committee of Senate) (also less than two pages of text).

181. University of Aberdeen, Academic Appeals-Guidance Note $\$ 4$ (Extract from Senate Minutes of 6 March 1985; amended by Minute 241 of 8 June 1988, Minute 46 of 25 October 1989, and Minute 25.2 of 13 October 1993) (hereinafter University of Aberdeen, Academic Appeals-Guidance Note].

182. Dennis Farrington, The Law Governing Students, in UNIVERSITIES AND THE LAW, supra note 14, at 73. See UNIVERSITY OF GLASGOW, CALENDAR: UNIVERSITY FEES AND GENERAL INFORMATION FOR STUDENTS 18 (1995-96) [hereinafter GLASGOW CALENDAR: FEES \& INFORMATION] (Board of Examiners may refer cases of academic dishonesty "to the Clerk of Senate, for action under the Code of Discipline, where there is prima facie evidence of an intention to deceive ${ }^{n}$ and more serious penalties seem appropriate); and University of Strathclyde, Guidelines and Procedures for Formal Examinations $\$ 11$ (1996) (plagiarism and collusion may be referred to Senate Discipline Committee).

183. Rules for the Conduct of Prescribed Assessments and Written Examinations for Degrees or Diplomas, in ABERDEEN CALENDAR, supra note 47, at 29, 30; see also University of Aberdeen, Code of Practice on Student Discipline $\$ \S 1.1 .8,4.1-4.4$.

184. University of Aberdeen, Academic Appeals-Guidance Note, supra note 181, 1 .

185. Id. Compare the two-month period provided for appeals at Heriot-Watt University. Heriot-Watt University, Reg. 36 (Student Appeals), \$ 5.3.7. 
Appeals to the Senate actually are heard by a committee on its behalf, with that committee's decision "deemed to be the decision of the Senate itself." 186 The Senate committee considers all representations made to it "by any interested parties." 187 Students who appeal receive copies of all written statements considered by the committee and are entitled to be present during the taking of all testimony. At such hearings, students may choose any person to accompany or represent them. Written notification of the committee's decisions goes to the students involved and to the Senate. ${ }^{188}$

Unsurprisingly, ${ }^{189}$ appeals against the decision of the Senate go to the Court. Neither body will consider the academic content of the challenged decision; rather, each will limit its consideration to the procedures employed in arriving at the decision. ${ }^{190}$ Nonetheless, either body may, in its discretion, order a reassessment of the "subject matter" rather than allow or reject the appeal. ${ }^{191}$

Appeals to the Court must be lodged in writing with the Secretary of the University, also within fourteen days. ${ }^{122}$ Although the appeal to the Court comes before a committee specially appointed by the Court, such appeals clearly get serious treatment: The Principal normally chairs such committees. The Court committee generally follows the procedures set out for appeals to the Senate. ${ }^{193}$

The procedures specified for academic challenges at the University of Glasgow provide more detail. Under its duty to "superintend" the teaching of the University, the Senate at Glasgow authorized Faculty Appeals Committees to "hear appeals in the first instance." 194 Each Faculty appoints such a committee, made up of the Dean and no more than twelve members

186. University of Aberdeen, Academic Appeals-Guidance Note, supra note 181, $\$ 5$.

187. $I d . \S 6$.

188. $I d . \$ \S 6,7$.

189. See Henderson \& Mattison, supra note 14, at 22.

190. University of Aberdeen, Academic Appeals-Guidance Note, supra note 181, 3. Compare STIRLING HANDBOOK, supra note 12, at 10 ("There is no appeal against the professional judgment of examiners ...").

191. University of Aberdeen, Academic Appeals-Guidance Note, supra note 181, §3.

192. Id. $\$ 7$. This feature reflects a nineteenth-century ordinance. See Limitations of Time for Appeals and Representations, Ordinance No. 5 (Gen. No. 2), Ordinances of the Commissioners under the Universities (Scotland) Act of 1889 (1891). Appeals to the Court at Heriot-Watt University must occur within twenty-eight days of announcement of the decision that is being appealed. Heriot-Watt University, Reg. 36 (Student Appeals), § 6.3.

193. University of Aberdeen, Academic Appeals-Guidance Note, supra note 181, at $\S$ 7. For procedures relating to appeals to the Court at Heriot-Watt University, see Heriot-Watt University, Reg. 36 (Student Appeals), §6. At Heriot-Watt, the Court appoints an ad hoc committee containing at least three Court members. The committee follows procedures "similar to" those provided for appeals to the Senate. Id. $\S \S 6.5 .4,-5$.

194. Glasgow Calendar: Fees \& INFORMATION, supra note 182, at 21. 
of the Faculty, which exercises full power to decide any academic ${ }^{195}$ appeal; three members constitute a quorum. ${ }^{196}$

A student wishing to appeal must so notify the Faculty Clerk in writing, setting out the grounds of the appeal and the remedies sought, within fourteen days of "intimation or publication" of the decision. ${ }^{197}$ The Dean, after consulting with two other members of the Committee, may make a preliminary determination that no competent grounds have been stated, that the appeal is not timely, or that the appeal should be referred to the Committee. The Committee generally meets within ten days of the appeal's lodging. The appellant, who is entitled to be heard upon request, ${ }^{198}$ may be accompanied or represented by another at any hearing. The appellant is entitled to the names of witnesses and any report not certified as confidential. ${ }^{199}$ At any hearing, the appellant may make (or have made by another) opening and closing statements and may examine witnesses. The Committee examines the appellant. The Committee decides the case, by majority vote, at the conclusion of its consideration of the appeal (or as soon thereafter as practical). The Convener of the Committee, in writing, informs the appellant and the appropriate University authorities of the decision. If the appeal succeeds, the Committee orders whatever relief it finds appropriate and notifies the Senate of the result, along with both reasons for the result and any recommendations. ${ }^{200}$

The student may appeal to the Senate against a decision of the Faculty Appeals Committee through a request to the Clerk of Senate. The rules limit the appeal, however, to allegations that new evidence has emerged that could not reasonably have been presented to the Faculty Appeals Committee; that a defective procedure tainted consideration at the Faculty level; or that

195. The committee's jurisdiction includes all academic decisions affecting students, but not proceedings under the Code of Discipline. Id. at 22.

196. Id. at 21-22.

197. Id. at 23 . The student appealing may already have had a significant process within the Faculty in connection with the appealed decision. See, e.g., id. at 60 . The suspension or exclusion of students in the Faculty of Arts must be confirmed by the Progress Committee of the Faculty. Id. See also University of Strathclyde, Reg. 9.11 (BA Regulations-Faculty of Arts and Social Sciences), $\$$ 9.11.27; and University of Strathclyde, Reg. 20.10 (Regulations for Certificates, Diplomas and Postgraduate Diplomas), § 20.10.11.

198. Compare STIRLING HANDBOOK, supra note 12, at 10 (Section 3.1 states: "In all appeals at undergraduate and at postgraduate level the Appeals Committees consider only written submissions; there is no provision for the appellant or other persons . . . to be present at the meeting of the Appeal Committee"). At Stirling, the decision of the Appeal Committee is final. Id. at 10,11 .

199. The Committee may not base its decision upon a confidential report unless the appellant has been informed of its substance. GLASGOW CALENDAR: FEES \& INFORMATION, supra note 182 , at 24.

200. Id. at 23-25. 
"disposal at the Faculty level was clearly unreasonable."201 The procedures before the Senate mirror those before the Faculty Appeals Committee. The grounds relied upon and the relief sought must be set out in the letter of appeal, due within fourteen days following the "intimation or publication" of the decision being appealed. The Clerk of Senate may, after consultation with two other members of the Senate Appeals Committee, dismiss the appeal as untimely or unworthy of consideration; refer the appeal to the appropriate Faculty Appeals Committee; or forward the appeal to the Senate Appeals Committee. ${ }^{202}$

The Senate Appeals Committee comprises the Clerk of Senate (the "Convener") along with ten members of the Senate ("persons of experience"). ${ }^{203}$ The Committee, of whom five constitute a quorum, may not include any members of the Court or anyone involved in making the original decision. The Senate, which has vested the Committee with full powers to hear and decide the appeal, ${ }^{204}$ merely receives a report of the Committee's decision. ${ }^{205}$

The Senate Appeals Committee meets within ten days of the appeal's noting, or as soon thereafter as practical. The appellant may insist upon a hearing and be accompanied there by a member of staff or other person whose representation the Committee may allow. The appellant may name those persons whom the appellant wishes the Committee to examine; may, in the event of a hearing, have access to any reports not certified as confidential; ${ }^{206}$ or may make a final statement or have a statement made on the appellant's behalf, final or not. The Committee examines the appellant or any other person deemed by the Committee as potentially helpful. Both

201. Id. at 25-26. The student must allege not only that the decision was clearly unreasonable, but also why. Id. at 26 .

For the grounds of appeal at the University of Stirling, see STIRLING HANDBOOK, supra note 12, at 10,11. For the grounds of appeal before the Undergraduate Appeals Committee at the University of Dundee, see Undergraduate Appeals Procedure-Regulations $\S 6(3)$, in DUNDEE CALENDAR, supra note 41, at 231-32.

202. Glasgow CALENDAR: FEES \& INFORMATION, supra note 182, at 27.

203. Id. at 26. The Dean of each faculty nominates one member; the Academic Development Committee nominates two others. Id. At Heriot-Watt University, appeals to the Senate are handled by an ad hoc committee appointed by the Principal and the Deans Committee and including at least three members of the Senate. Heriot-Watt University, Reg. 36 (Student Appeals), § 5.3.5. The ad hoc committee submits its report, including recommendations, to the Senate for its approval. Id. \$ 5.3.6(e).

204. At Heriot-Watt University, the Senate has delegated to the Student Progress Committee all appeals relating to student progress. Heriot-Watt University, Reg. 36 (Student Appeals), \& 3.2.

205. Glasgow CALENDAR: FEes \& INFORMATION, supra note 182, at 26.

206. Id. at 28. Like the Faculty Appeals Committee, the Senate Appeals Committee may not base its decision on a confidential report unless the appellant has had access to its substance. Id. 
the appellant and members of the university staff may interview witnesses through the Committee. The Senate Appeals Committee may remand the case to a Faculty Appeals Committee if evidence available to the Senate committee had not been made available to the faculty committee or if the procedure before the faculty committee had been defective. ${ }^{207}$

The Committee, which decides cases upon a majority vote, may dismiss even a meritorious appeal if the student has suffered no material disadvantage. The Clerk notifies the student and the appropriate university authorities of the decision. If the appeal is upheld, the Committee so notifies the Senate, giving its reasons for that result. ${ }^{208}$

Under Parliamentary legislation, ${ }^{209}$ the University Court may review Senate decisions appealed by any "member" of the university. Accordingly, students aggrieved by a decision of the Senate Appeals Committee may challenge that decision in the Court. That appeal must be lodged with the Secretary of the University Court no later than twenty-eight days after promulgation of the decision. ${ }^{210}$ The University Calendar specifies no further procedures for such an appeal. ${ }^{211}$

\section{B. Disciplinary}

University Courts have the power to set by resolution the disciplinary codes of universities for offenses punishable by "expulsion or rustication." But that power, at least in the "older" universities, can be exercised only on

207. Id. at 28-29. In the second situation, a newly formed faculty committee hears the remand. Id. at 29.

208. Id. at 29.

209. THE UNIVERSITIES (SCOTLAND) ACT $1889, \S 6(2)$.

210. Glasgow CALENDAR: FEes \& InFORMATION, supra note 182, at 29-30.

211. For information on academic appeals at other universities, see ST. ANDREWS CALENDAR, supra note 47, at 4.11; EDINBURGH CALENDAR, supra note 40, at B-5 (Faculty of Arts), C-3 (Faculty of Divinity), D-3 (Faculty of Law), and G-8 (Faculty of Science and Engineering); University of Strathclyde, Reg. 20.10 (Regulations for Certificates, Diplomas and Postgraduate Diplomas), $\S 20.10 .11$; and University of Strathclyde, Reg. 6.10 (Regulations Governing the Hearing of Student Appeals by the Appeals Committee of Senate); Heriot-Watt University, Reg. 36 (Student Appeals); and STIRLING HANDBOOK, supra note 12, at $10-11$.

At the University of Dundee, students appeal to a committee of the Senatus Academicus entitled the Termination of Studies (Appeals) Committee. (Its name suggests the limitation of its jurisdiction.) Upon receipt of an appeal, the Secretary of the University refers it to the appropriate Faculty Board or Faculty Committee for consideration and recommendations. The decisions of the Committee are final, though reports go to the Senatus Academicus and to the appropriate Faculty Board. Termination of Studies (Appeals) $\S 1,7,12$, in DUNDEE CALENDAR, supra note 41, at 227-28. Other appeals go to a separate Undergraduate Appeals Committee. Undergraduate Appeals Procedure-Regulations $\$ \S 1,6(1)$, in DUNDEE CALENDAR, supra note 41 , at 231. 
the recommendation of the Senate. ${ }^{212}$ The net effect vests primary responsibility for student discipline in the Senate, with appellate functions located in the Court. ${ }^{213}$ Scottish universities have devoted significant energy to developing such codes. Interestingly, most such codes in the United Kingdom today derive "from work done at the height of the period of student unrest in Europe and the United States from 1968 to 1974, occasioned by a variety of contemporary issues such as the Vietnam War . . . [and] civil rights . . . ."214 During that period, nonetheless, Aberdeen remained relatively calm..$^{215}$

Attitudes toward university discipline have been much influenced by the so-called Zellick Report, named for Graham Zellick, ${ }^{216}$ who chaired the committee that produced it in 1994. More formally known as the Final Report of the Task Force on Student Disciplinary Procedures, the document does not purport to constitute a model code of procedure, though it proffers some model provisions regarding the central issues confronted. Rather, the Zellick Report puts forth a set of commended principles, along with a suggested definition of misconduct, for universities in the United Kingdom. ${ }^{217}$

Importantly, the document makes clear that universities no longer stand in loco parentis "in any legal sense." 218 Searching for the permissible scope of universities' disciplinary authority, the Zellick Committee found no

212. The UNIVERSITIES (SCOTLAND) ACT 1966 (SChedule 2), § 4. See also CharTER

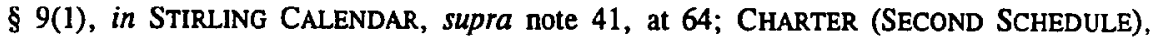
STATUTE $10, \S 4(\mathrm{e})$ and ( $\mathrm{f}$ ), in STIRLING CALENDAR, supra note 41, at 78; ChARTER of HERIOT-WATT UNIVERSITY (SCHEDULE), STATUTE XIII, § 4(p). For more on the sources of disciplinary power at universities in the United Kingdom, see Eduardo Ustaran, Discipline and the Internet, 1 U. \& C. EDUC. L. NETWORK REP. 4, 5 (1996).

213. University of Edinburgh, General Statement on Student Discipline § II (1994).

214. Farrington, supra note 15 , at 7.

215. At Aberdeen, in common with most British universities, but in sharp contrast to many universities in Europe and America, these [decades, from 1945 to 1981,] were peaceful decades. "Outside political pressures and the great protest movements of the 1960 s and 1970s made very little impression here, while the internal challenge to traditional staff hierarchies was also muted." Carter, supra note 65, at 95 . Perhaps some of the reticence stemmed from parochialism or introversion. See id. at 130. Reports of nineteenth-century graduation ceremonies betray no such reticence: " $[E]$ ven the principal's prayers and sermon were interrupted by ribaldry and songs," and "running jokes and humorous sallies" bombarded the graduands. ANDERSON, supra note 95, at 30.

216. At the time, Graham Zellick was Principal of Queen Mary and Westfield College, University of London.

217. COMMITTEE OF VICE-CHANCELLORS AND PRINCIPALS OF THE UNIVERSITIES OF THE UNITED KINGDOM, FINAL REPORT OF THE TASK FORCE ON STUDENT DISCIPLINARY PROCEDURES 1 (1994) [hereinafter Zellick Report].

218. Id. \1. 
answers in the statutes, charters, or the like; it has been left to the institutions themselves to define that scope. ${ }^{219}$

The Committee therefore turned to the three fundamental principles that, in its view, support institutional exercise of disciplinary power: 1) a university is a community, a fact requiring certain standards of conduct and placing on that institution duties of care and responsibility toward its members; 2) a university is an organization committed to certain standards and values inherent to its mission; and 3) a university, like other organizations, is entitled to protect its good name and reputation. ${ }^{220}$

The Zellick Committee urges that disciplinary codes combine fairness with simplicity and efficiency; the codes should not imitate criminal law, either substantively or procedurally. ${ }^{221}$ Interestingly, the Committee discourages "plea bargaining" or negotiation during university disciplinary proceedings. ${ }^{222}$ Serious penalties should be imposed only under the disciplinary code and therefore the codes should incorporate by reference serious violations of other campus provisions, for example, the library's rules or a campus sexual-harassment policy. ${ }^{223}$

Disciplinary codes should not deal with misconduct arising from mental ill-health. $^{224}$ Nor should the code address conduct occurring prior to the student's matriculation unless its seriousness raises serious question regarding the student's fitness 1) to remain a member of the community, for example, with regard to the safety of others; or 2) to practice the profession targeted by a vocational course undertaken by the student. ${ }^{225}$

The Committee appended to the Zellick Report "suggestions" for disciplinary codes, some of which implement points made in the Report itself. Rules of evidence applicable in the courts need not apply to disciplinary proceedings and proof by a preponderance of the evidence-not beyond a reasonable doubt-should underlie the hearing's conclusions. ${ }^{226}$ Students should be entitled to be accompanied, assisted, or represented at hearings or appeals. More serious offenses should be dealt with not by a university official, but by a "small committee of no more than three,"227

219. Id. $\ 2$.

220. Id. 13.

221. Perhaps the Committee had in mind codes like that at Strathclyde, which speak of appeals "on a point of law or fact or on a point of mixed law and fact." See University of Strathclyde, Reg. 5 (Regulations for Student Discipline), § 5.7.19.

222. Zellick Report, supra note 217, 1 \$34-35.

223. Id. \१ 36-37. For an example, see Code of Discipline § 4, in GLASGOW CALENDAR: FEES \& INFORMATION, supra note 182, at 38.

224. Zellick Report, supra note $217,138$.

225. Id. \40.

226. Id. at app. $\mathrm{V}, \S \mathrm{A}(2)$

227. Id. $\S \mathrm{C}(6)$. Under this definition, the only alternative to a committee of three would seem to be a committee of two, awkward even without the need to have both students and staff 
containing student and staff members. One appeal (but not a re-hearing) should be permitted for more serious cases. The appeal should be heard by a committee no larger than the hearing committee, and the decision should be final. ${ }^{228}$

A separate appendix provides a model definition of "misconduct." The provision first broadly states the essence of misconduct: "improper interference . . . with the proper functioning or activities of the institution, or those who work or study [there], or which otherwise damages the institution." Any finding of misconduct must be shown to fall under this general rubric. The statement then lists fourteen more specific categories of conduct of which the university might take notice, including sexual or racial harassment, certain conduct that constitutes a criminal offense, and behavior bringing the university into disrepute. ${ }^{229}$

Except in one major respect, the code of discipline ${ }^{230}$ at the University of Aberdeen does little violence to the suggestions of the Zellick Report, which prompted the code's revision in June 1996. ${ }^{231}$ Aberdeen's general definition of misconduct mirrors that proffered by the Zellick Report: "improper interference . . . with the proper functioning or activities of the institution, or with those who work or study [there], or action which otherwise damages the institution." 232 The code goes on to cite fourteen specific categories included in, but not exhaustive of, the general definition. ${ }^{233}$ These fourteen virtually replicate the list of specifics set out in

represented.

228. Id. § $\mathrm{C}(7)$.

229. Id. at app. VI; $\$ \S 1-4$.

230. See University of Aberdeen, Resolution No. 196 of 1996 (Code of Practice on Student Discipline).

231. Webb Interview, supra note 163. Mr. Webb noted that one would expect in Aberdeen's new code little serious disagreement with Zellick since the latter issued under the auspices of the Committee of Vice-Chancellors and Principals. Id.

232. University of Aberdeen, Resolution No. 196 of 1996 (Code of Practice on Student Discipline), § 1.1. Compare Ordinance 40: Discipline § 3(2)(ii), in DunDEE CaLENDAR, supra note 41 , at $198-210$ (prohibiting conduct, on- or off-campus, that "is prejudicial to the peace, order, good government or reputation of the university").

233. The code at Glasgow states that there is "no definitive enumeration of disciplinary offenses," and then provides nine "examples." Code of Discipline $\S 3$, in GLASGOW CALENDAR: FeEs \& INFORMATION, supra note 182, at 38 . The St. Andrews code first lists nine relatively specific categories, then states that the list "is demonstrative only and must not be taken as exhaustive or exclusive." University of St. Andrews, Resolution of the University Court 1992 No. 4, §4. The University of Edinburgh lists five quite general categories but has no language suggesting the list to be merely illustrative. University of Edinburgh, General Statement on Student Discipline § III. See also University of Strathclyde, Reg. 5 (Regulations for Student Discipline), $\S \S 5.1 .8$ and 5.4.1 (examples are "demonstrative only"). A student who "uses offensive or improper language or behaves in an offensive or improper way" may violate Strathclyde's code. Id. \$ 5.4.6. See also Heriot-Watt University, Ordinance 9 (Student Discipline), $\S 2.3$ (list of offenses is "demonstrative only"). For sheer" 
the Zellick Report and include violent, indecent, "disorderly, threatening or offensive behavior or language"; 234 "sexual or racial harassment of any student, member of staff, other employee, or . . visitor"; 235 "breach of the provisions of any University Code of Practice, rule or regulation" specifying that breach to be a violation "under this Code;"236 "examination offences, including cheating . . . [and] plagiarism" $; 237$ and certain criminal conduct. ${ }^{238}$

unpredictability, the University of Stirling perhaps trumps all other Scottish universities: After listing seven categories of misconduct-some general, others more specific-the code warns that the "University Secretary with the agreement of the Assessor . . . may determine what may in addition and in exceptional circumstances constitute an offence [sic]." Ordinance 2: Code of Student Discipline, General Statement on Disciplinary Offences $\S 7$, in STIRLING CALENDAR, supra note 41 , at 125 .

234. University of Aberdeen, Resolution No. 196 of 1996 (Code of Practice on Student Discipline), § 1.1.3.

235. Id. $\S 1.1 .6$.

236. Id. $\$ 1.1 .7$. Compare University of Edinburgh, General Statement on Student Discipline § II; and Ordinance 40: Discipline § 3(1) and (2), in DUNDEE CALENDAR, supra note 41 , at 198 .

237. University of Aberdeen, Resolution No. 196 of 1996 (Code of Practice on Student Discipline), § 1.1.8.

238. Id. \$1.1.11. For the definition of misconduct at other universities, see University of St. Andrews, Resolution of the University Court 1992 No. 4, § 4; Code of Discipline § 2, in GLASGOW CALENDAR: FEes \& INFORMATION, supra note 182, at 38; University of Edinburgh, General Statement on Student Discipline $\S$ III; Ordinance 2: Code of Student Discipline, General Statement on Disciplinary Offences, in STIRLING CaLENDAR, supra note 41 , at 125 . It should be noted that student unions reserve to themselves the right to discipline students regarding misconduct occurring on union premises, at union meetings, or related to union elections. FARRINGTON, supra note 17, at 197. For procedures attending such discipline, see $i d$. At the University of Michigan, "violations," that is, "behaviors which contradict the essential values of the University community," comprise fourteen categories of conduct that cover, among other things, physically harming ("including killing"); sexual assault; stalking; certain conduct relating to firearms, explosives, and drugs; theft; disruption of the University's instructional or research program; falsifying university documents, including identification and meal cards; violating state or federal law if the conduct has a "serious impact" on the University community; and violating University computer policies. University of Michigan, Code of Student Conduct (1996). "Student Misconduct" at Indiana University includes three categories. "Academic misconduct" is defined as "any activity which tends to compromise the academic integrity of the institution and undermine the educational process." Academic misconduct includes cheating, fabrication, plagiarism, interference with another student's work, violation of course rules, and facilitating academic dishonesty. Indiana University, Code of Student Ethics, Part III, $\$$ A. The second category, "Personal Misconduct on University Property," sets out 24 subcategories of proscribed conduct, themselves including disorderly conduct, arson, unauthorized possession of firearms, sexual harassment, verbal abuse and violations of federal or state law. Id. $\S \mathrm{B}$. The third category, "Personal Misconduct Not on University Property," applies to off-campus acts that occur during University activities or that "relate to the security of the University community or the integrity of the educational process." Id. § $\mathrm{C}$. This wonderfully broad definition includes-but is not limited to-arson, battery, fraud, and sexual assault. Id. Interestingly, the category also includes "altering academic transcripts" and "trafficking in term papers," 
The code sets out a relatively simple, though comprehensive, procedure. ${ }^{239}$ Anyone-staff member, student, or member of the general public-may file a complaint with the Secretary of the University. ${ }^{240}$ Formal complaints that appear to involve a matter of discipline go to an Investigating

id., conduct which might better fit within "academic misconduct."

239. At the University of Michigan, any student, faculty member or staff member may submit a complaint alleging a violation of the Code of Student Conduct. Unless violence is involved, both parties may agree to mediation; if violence is involved, the University's Resolution Coordinator must also agree to mediation. Mediated agreements may not be appealed. If the matter is not resolved through mediation, it is arbitrated, according to the accused student's choice, by a University Resolution Officer or a Student Resolution Panel. Arbitrated resolutions go to the Dean of Students, who may accept or modify the recommendations but may not increase a sanction to suspension or to expulsion. Each party may appeal from this result on the basis of a failure to follow procedures, insufficient evidence, insufficient or excessive sanction, or new evidence. The Appeals Board is comprised of one student appointed by the Michigan Student Assembly, one faculty member appointed by the Faculty Senate, and an administrator appointed by the President. The Board recommends to the Vice President for Student Affairs one of three courses of conduct: confirm the decision reached by the arbitration process, alter the sanctions, or submit for rearbitration. The Vice President may accept or modify the recommendation, but may not increase a sanction to suspension or expulsion. University of Michigan, Code of Student Conduct (1996).

At Indiana University, proceedings relating to allegations of personal misconduct or of "misconduct unrelated to a particular course" may be initiated by any student or any member of the University faculty; administration, or staff. Such complaints come before the Dean of Students, who decides whether disciplinary proceedings should ensue. Full notice of the charges are provided to the student, who is ordered to appear before the Dean for an informal conference. The student may be accompanied by an advisor, whose participation at the conference is severely limited. The student's choice not to answer questions will not be taken as an admission of guilt. If the Dean of Students does not dismiss the charge, the Dean proposes a penalty, which may range from a simple reprimand through expulsion from the University. The student may accept that penalty or, by rejecting it, elect to take the case to a hearing commission, made up of one student and two faculty members. This formal hearing carries with it full due-process protections: renewed notice of the charges, discovery of witnesses' names (the student must in turn furnish a list of witnesses the student might offer), the right to a public hearing on request, the right to representation at the hearing, the right to examine and cross-examine witnesses, and a privilege against self-incrimination. A transcript of the hearing is made. The University has the burden of proof-"clear and convincing evidence" - and a majority of the hearing commission must agree. If the commission finds the student guilty, it may choose any of the sanctions that had been available to the Dean of Students. (These procedures do not govern the alleged violation of campus motor-vehicle or residence-hall regulations.) Indiana University, Code of Student Ethics, Part IV, §§ C, D (1995).

240. University of Aberdeen, Resolution No. 196 of 1996 (Code of Practice on Student Discipline), § 2.1. Nonetheless, complaints of cheating "in a prescribed degree assessment should normally be made through the Head of Department (and should not be dealt with as part of academic assessment). The Head of Department normally investigates the matter prior to filing a complaint." Id. $\$ 4.1$. 
Officer, ${ }^{241}$ appointed by the Senate. ${ }^{242}$ After investigation, that officer may dismiss a complaint or find the matter a minor breach suitable for direct disposition by the Investigating Officer. $^{243}$ In the latter case, the Investigating Officer may, for non-academic cases, impose a written or oral reprimand, restitution, compensation, fine (of up to approximately \$375), suspension from the University for up to four weeks, or a combination of these. ${ }^{244}$ The student may appeal the finding or penalty to a Disciplinary Committee, which may waive, uphold, reduce, or increase the penalty. ${ }^{245}$

241. For non-academic matters, the Regent normally serves as Investigating Officer. Id. $\S 2.1$.

242. Id.

243. Id. § 6.1. Compare Ordinance 40: Discipline \$7, in DUNDEE CALENDAR, supra note 41 , at 200 . With regard to the treatment of minor cases at other universities, see Code of Discipline § 12, in GLASGOW CALENDAR: FEES \& INFORMATION, supra note 182, at 40; Ordinance 40: Discipline $\$ \S 7,8$, in DUNDEE CALENDAR, supra note 41, at 200-01.

244. For the parallel penalties at St. Andrews, see University of St. Andrews, Resolution of the University Court 1992 No. 4, § 6(a); at Edinburgh, see University of Edinburgh, Code of Student Discipline $\S 2$ (b); at Stirling, see Ordinance 2: Code of Student Discipline, Summary Powers to Impose Penalties $\$ 2.4$, in STIRLING CALENDAR, supra note 41, at 114-15 (providing, inter alia, for sureties guaranteeing future behavior); at Heriot-Watt, see HeriotWatt University, Ordinance 9 (Student Discipline), § 5.11; at Dundee, see Ordinance 40: Discipline $\S 15(1)$, in DUNDEE CALENDAR, supra note 41, at 209. In traffic cases at Dundee, an interesting penalty applies to the second offense: " $[A] n$ inconvenient sticky notice will be fixed to the wind-screen of the car, which the offender will have the task of removing." Car Parking Regulations $\S 14(\mathrm{~b})$, in DUNDEE CALENDAR, supra note 41, at 221.

245. University of Aberdeen, Resolution No. 196 of 1996 (Code of Practice on Student Discipline), $\S 7.1$. For the penalties in academic cases, see $i d$. $\$ \S 4.2-4.4$.

Although the Aberdeen system allows an increase of penalty on appeal, that apparently has not happened. Nonetheless, letters informing the student of the right to appeal at least impliedly point out the risk. Webb Interview, supra note 163 . So, too, at Stirling, where penalties are subject to increase on appeal, no such increase has taken place in at least the last ten years; nonetheless, students there are reminded of the possibility in order to dissuade appeals. As it turns out, $90 \%$ of students choose not to appeal. Farrington Interview, supra note 6. At the University of Strathclyde, penalties may be increased on appeal, but that has never happened. In any event, the Clerk of the Senate informs students of that possibility before they decide whether to appeal. Mellows Interview, supra note 6 . Heriot-Watt allows penalties to be increased on appeals to the Discipline Committee and to the Discipline Appeals Board, see Heriot-Watt University, Ordinance 9 (Student Discipline), §§ 5.17, 5.39, but apparently not in appeals to the Court. See id. $\S 5.40$. At Heriot-Watt, penalties have never been increased on appeal; the provision for such increases, however, has been invoked to dissuade appeals. Parkinson Interview, supra note 6. See also University of Edinburgh, Code of Student Discipline $\S \S 4(b)(x i), 5(b)(x i)$.

For the parallel rights of appeal at Edinburgh, see University of Edinburgh, Code of Student Discipline $\S 4(\mathrm{~b})$; at Heriot-Watt, see Heriot-Watt University, Ordinance 9 (Student Discipline), § 5.13-5.17; at Dundee, see Ordinance 40: Discipline $\$ \S 11,13$, in DuNDEE CALENDAR, supra note 41, at 203-04, 2-6. Dundee also allows the committee hearing the appeal to increase the penalty. Id. $\$ 13(6)(\mathrm{ii})$. Appeals at Dundee are decided by majority vote. Id. § 13(9). Stirling uses a "Minor Offenses Appeal Board." Ordinance 2: Code of 
If, after investigation, the Investigating Officer finds a major breach of discipline, or a minor one inappropriate for direct disposition by the Investigating Officer, the matter goes to a Disciplinary Committee. ${ }^{246} \mathrm{~A}$ Disciplinary Committee may impose an oral or written reprimand, restitution, compensation, fine (up to approximately $\$ 1500$ ), exclusion from specified facilities, suspension or expulsion from the University, or any combination of these. ${ }^{247}$ In exceptional cases presenting danger to the University community, the Principal may take immediate action to exclude a student temporarily from the University (or from certain aspects of it) pending a disciplinary hearing or a criminal trial..$^{248}$

Student Discipline, Minor Offences Appeal Board § 3, in STIRLING CALENDAR, supra note 41, at 115. The Board may increase penalties, and its decisions are final. $1 d$. $\$ \S 3.2 .4,3.2 .5$. For proceedings before this Board, see id. $\$ 7.2$, in STIRLING CALENDAR, supra note 41, at 119.

246. University of Aberdeen, Resolution No. 196 of 1996 (Code of Practice on Student Discipline), $\$ \S 2.2,6.1$. In any event, cases reflecting “any doubt or difficulty” should be referred to a Disciplinary Committee. Id. $\$ 6.1$.

At the University of Edinburgh, a "Principal and Deans' Committee" stands between the Authorized Officer and the disciplinary committee; after the Authorized Officer refers the case to the Principal and Deans' Committee, that Committee may remand the case to the Authorized Officer for disposition. University of Edinburgh, Code of Student Discipline $\S$ $5(\mathrm{a})(\mathrm{I})$.

247. University of Aberdeen, Resolution No. 196 of 1996 (Code of Practice on Student Discipline), $\S 9.1$. For the penalties available to the disciplinary committee at St. Andrews, see University of St. Andrews, Resolution of the University Court 1992 No. 4, § 6(b); at Edinburgh, see University of Edinburgh, Code of Student Discipline $\S 3(c)$; at Stirling, see Ordinance 2: Code of Student Discipline, Powers to impose penalties $\$ 4.3$, in STIRLING CALENDAR, supra note 41, at 116; at Strathclyde, see University of Strathclyde, Reg. 5 (Regulations for Student Discipline), §§ 5.4.11-5.4.18; at Heriot-Watt, see Heriot-Watt University, Ordinance 9 (Student Discipline), \$ 2.5; at Dundee, see Ordinance 40: Discipline $\S 15(2)$, in DUNDEE CALENDAR, supra note 41 , at 209 . Decision-makers at Dundee may publicize as they see fit any penalties they assess. Id. $\$ 15(3)$.

248. University of Aberdeen, Resolution No. 196 of 1996 (Code of Practice on Student Discipline), $\S \S 11.1,11.2$. In the Principal's absence, a Vice-Principal may so act. Id. $\S \S$ $11.1,11.2$. For the limitations and procedures attending such situations, see id. $\S \S 11.1$ to 11.10. The action must be "urgent and necessary," and the justification set out in writing and provided to the student. Id. $\S 11.6$. The student has the right to a personal appearance before the Principal, usually prior to the exclusion, id. $\S 11.7$; to an appeal, if the exclusion lasts more than four weeks, id. $\S 11.9$; and to periodic review by the Principal, id. $\$ 11.10$.

In "major cases" at St. Andrews, the Authorized Officer (the Hebdomadar) may suspend a student from all or part of the University until disciplinary procedures terminate. University of St. Andrews, Resolution of the University Court 1992 No. 4, § 5(a)(ii). See also STIRLING HANDBOOK, supra note 12, at 13; and Ordinance 30: Exclusion from University Campus, in STIRLING CALENDAR, supra note 41, at 144.

See also University of Strathclyde, Ordinance 12 (Student Discipline), § 2; and HeriotWatt University, Ordinance 9 (Student Discipline), $\S 1.6$ (Principal may exclude student from all or part of the University "without assigning any reason," but student may appeal to Senate). 
A Disciplinary Committee comprises a senior member of the Senate, who chairs it, and four other members of the Senate-two staff and two student members-selected by the Secretary of the University from the Disciplinary Committee Panel. ${ }^{249}$ The student under investigation may insist that no student be included on the Committee. Moreover, for cause shown, that student may challenge any particular person's appointment to the Committee. 250

Hearings before an Investigating Officer ${ }^{251}$ resemble closely those before a Disciplinary Committee. ${ }^{252}$ Before either decision-maker, the student is entitled to be informed in writing of the allegations and of the time and place of the hearing. ${ }^{253}$ The student may be accompanied or represented by any person chosen by the student. ${ }^{254}$ All oral evidence must be taken in the presence of the student or, with the student's approval, of the student's representative. The student receives copies of all written submissions. ${ }^{255}$ The student (or representative) may address questions to the Investigating Officer or to the Convener of the Committee, as the case may be, and to any

249. University of Aberdeen, Resolution No. 196 of 1996 (Code of Practice on Student Discipline), $\$$ 8.1. This Panel comprises in turn twelve staff and seven student members of the Senate appointed by the Senate. Id. For the composition of the disciplinary committees at other Scottish universities, see University of St. Andrews, Resolution of the University Court 1992 No. 4, § 3; Code of Discipline $\S 7$, in Glasgow Calendar: FeEs \& INFORMATION, supra note 182, at 39; University of Edinburgh, Code of Student Discipline $\S$ 3; Ordinance 40: Discipline $\S 5(2), 5(3)$, and 12(1), in DUNDEE CALENDAR, supra note 41, at 199, 205; Ordinance 2: Code of Student Discipline, Discipline Committees $\$ 4$, in STIRLING CALENDAR, supra note 41, at 116; University of Strathclyde, Reg. 5 (Regulations for Student Discipline), \$ 5.2; and Heriot-Watt University, Ordinance 9 (Student Discipline), §4.

250. University of Aberdeen, Resolution No. 196 of 1996 (Code of Practice on Student Discipline), § 8.1.

251. See id. $\$ 12$.

252. See id. $\$ 13$.

253. Id. $\S \S 12.2,13.1$. The notice period should normally be at least seven days during term-time and fourteen days out of term. Id.

254. So, too, with regard to the disciplinary committee at Glasgow. See Code of Discipline $\S 16$, in Glascow CALENDAR: FEes \& INFORMATION, supra note 182, at 40 . At St. Andrews, the student may be accompanied by another member of the University. University of St. Andrews, Resolution of the University Court 1992 No. 4, \& 5(c)(iv). At hearings before the disciplinary committee at Dundee, the student may be represented "by a member of the academic staff, or by a member of the Graduates' Council, or by a solicitor or advocate ...." Ordinance 40: Discipline § 9(3)(ii), in DUNDEE CALENDAR, supra note 41, at 199. At Strathclyde and at Heriot-Watt, students may be legally represented or accompanied by a person of their choice. University of Strathclyde, Reg. 5 (Regulations for Student Discipline), § 5.7.14; Heriot-Watt University, Ordinance 9 (Student Discipline), § 5.18(c).

255. University of Aberdeen, Resolution No. 196 of 1996 (Code of Practice on Student Discipline), $\S \S 12.1 .3,13.2 .4$. 
witnesses regarding their statements or written submissions. The student (or representative) may give a concluding statement. ${ }^{256}$

In a major and surprising departure from the Zellick Report and the practice at some universities, ${ }^{257}$ the burden of proof applied by the Investigating Officer or by the Disciplinary Committee is "beyond a reasonable doubt."258 Decisions of the Investigating Officer, unless appealed by the student, and, in any event, of the Disciplinary Committee are deemed decisions of the Senate itself. ${ }^{259}$ Students disciplined under these procedures

256. Id. $\S \S 12.1 .3,13.2 .4$, and 13.2.5. Compare Code of Discipline $\$ \S 20,21$, in Glasgow CALENDAR: FEes \& INFORMATION, supra note 182, at 41-42. At Glasgow, the student is entitled, but cannot be required, to give evidence. Id. $\S 20(\mathrm{f})$.

For proceedings before the disciplinary committee at St. Andrews, see University of St. Andrews, Resolution of the University Court 1992 No. 4, § 5(c). The committee may decide on a majority vote of the members present. Id. $\S 5(\mathrm{c})(\mathrm{x})$.

For proceedings before the disciplinary committee at Edinburgh, see University of Edinburgh, Code of Student Discipline $\S 5(\mathrm{a})$. At Edinburgh, both the student, id. $\S$ $5(\mathrm{a})(\mathrm{v})(2)$, and the University, id. $\S 5(\mathrm{a})(\mathrm{ix})$, must give advance notice of documents and witnesses to be used. The student is entitled to a full, written explanation of the Committee's decision. Id. $\S 5(\mathrm{a})$ (xvi).

For proceedings before the disciplinary committee at Dundee, see Ordinance 40: Discipline $\S 12$, in DUNDEE CALENDAR, supra note 41, at 205. At Dundee, the Presenting Officer may examine the student, id. $\S 12(6)$; the panel may decide by majority vote, though it may not "find an allegation against a student proved unless at least four members are of that opinion," Id. §12(11).

For proceedings before the disciplinary committee at Strathclyde, see University of Strathclyde, Reg. 5 (Regulations for Student Discipline), $\$ 5.6$. The code provides for reciprocal discovery of names of witnesses. See id. $\$$ 5.7.14.

For proceedings before the disciplinary committee at Heriot-Watt, see Heriot-Watt University, Ordinance 9 (Student Discipline), $\S 5.18-5.30$. The code provides for reciprocal discovery. Id. $\S 5.19$.

For proceedings before the disciplinary committee at Stirling, see Ordinance 2: Code of Student Discipline, Major offences procedure $\$ 8$, in STIRLING CALENDAR, supra note 41 , at 120-21. At Stirling, the student may be accompanied by a legal representative "or by another person." Id. $\$ 8.1 .1$ (c), at 121 . Both sides must provide advance notice of documents and witnesses. Id. $\S \S 8.1 .1$ (d) and 8.1.7, at 121 . Decisions are by majority vote. Id. $\S 8.1 .11$, at 122. At Stirling, decision-makers, where no provision of the code covers a matter, must proceed according to the rules of natural justice. Id. $\$ 1.3(\mathrm{c})$, at 112 .

257. See, e.g., Code of Discipline $\S 20(\mathrm{I})$, in Glasgow Calendar: Fees \& INFORMATION, supra note 182, at 41 ("balance of probabilities").

258. University of Aberdeen, Resolution No. 196 of 1996 (Code of Practice on Student Discipline), § 3.1. The University of Edinburgh also applies a “beyond a reasonable doubt” standard. See University of Edinburgh, General Statement on Student Discipline § I.

The Code at the University of Michigan specifies no burden of proof for any of the decision-makers involved in its procedures. See University of Michigan, Code of Student Conduct (1996). The hearing commission at Indiana University applies a "clear and convincing" standard. Indiana University, Code of Student Ethics Part IV, $\$ D(5)(\mathrm{g})$.

259. University of Aberdeen, Resolution No. 196 of 1996 (Code of Practice on Student Discipline), §14.1. 
may appeal to the University Court by filing with the Secretary of the University, within fourteen days of the decision appealed, a written statement of the grounds underlying the appeal. ${ }^{260}$ At universities in the United States, the provision of such a routine appeal to the governing body would be rare indeed. 261

Certain alleged minor breaches may be reported to or resolved by a Warden of a Hall of Residence, the Librarian, the Director of the computing center, or the Director of Physical Education. Penalties imposed by these officials, however, are limited to a fine (up to approximately $\$ 150$ ),

260. Id. $\S 15.1$. For the process attending appeals to the court at St. Andrews, see University of St. Andrews, Resolution of the University Court 1992 No. 4, \& 7 (appeals normally heard by a court committee comprising the three most senior lay members of the Court available; "fresh" evidence to be heard only on showing of good cause; penalty can be raised).

For the process attending such appeals at Glasgow, see Code of Discipline $\$ \S 22-29$, in GLASGOW CALENDAR: FEES \& INFORMATION, supra note 182, at 42. At Glasgow, the Court may, "on cause shown," hear additional evidence. Id. $\S 27$. The Court may not increase the penalty. Id. $\$ 28$.

For the process attending such appeals at Edinburgh, see University of Edinburgh, Code of Student Discipline $\S 5(\mathrm{~b})$. The Court may sit as a full Court or as a committee reporting to the Court. Id. $\S 5$ (b)(ii). The appellant may be legally represented or accompanied by a member of the University. Id. For "cause shown," the appellant may present additional evidence, whereupon the same right falls to the University. Id. §5(b)(5).

For the process attending such appeals at Dundee, see Ordinance 40: Discipline $\S 14$, in DUNDEE CALENDAR, supra note 41, at 207-09. The Court may rehear certain cases in their entirety; in such cases, it follows, in large measure, the proceedings specified for the disciplinary committee. Id. $\S 14(0)$. The Court may increase a penalty appealed against. Id. $\S 14(10)$ (ii).

See also Charter (SECOND Schedule), STATUTE 18: APPEALS By STUdents, in STIRLING CALENDAR, supra note 41, at 97. Stirling has an Appeal Board, whose decision is final. Id. § 4. The Appeal Board may increase the penalty imposed by the discipline committee. Ordinance 2: Code of Student Discipline \$\$ 5.2.6. and 8.2.12, in STIRLING Calendar, supra note 41 , at 117,124 . Strathclyde has a Discipline Appeals Board. University of Strathclyde, Reg. 5 (Regulations for Student Discipline), § 5.1.10. For its composition, see id. § 5.3. For procedures before that Board, see id. § 5.8. Heriot-Watt has a Discipline Appeals Board. See Heriot-Watt University, Ordinance 9 (Student Discipline), $\S 5.31$. For its composition, see $i d$. $\$ 4.10$. Students unhappy with the result there may appeal, yet again, to the Court. Id. $\$ 5.40$.

For the appeals process at Indiana University, see supra note 239 . At Indiana University, appeals from decisions of the hearing commission lie with a "review board," consisting of one student, one faculty member, and one administrative officer, who presides. No additional evidence is taken. Decisions are by majority vote and are final. Indiana University, Code of Student Ethics, Part IV, $\S \mathrm{D}(6)$.

261. At Indiana University, for example. Telephone interview with Pamela Freeman, Assistant Dean of Students and Director of Student Ethics and Anti-Harassment Programs, Indiana Univ. (Dec. 5, 1995) [hereinafter Freeman Interview]. A former President said Indiana's board would not get involved in $99.9 \%$ of such cases. Telephone interview with John Ryan, President Emeritus, Indiana Univ. (Dec. 7, 1995) [hereinafter Ryan Interview]. 
expulsion from the residence hall, or suspension of rights with regard to the library, the computing center, or the department of physical education, as appropriate. ${ }^{262}$ If the student rejects the disposition, the case goes to an Investigating Officer or to a Disciplinary Committee. ${ }^{263}$

\section{THE COURTS AND THE CULTURE}

\section{A. The Paucity of Litigation Regarding University Decisions}

As in Australia, ${ }^{264}$ university students in Scotland do not bring their academic and disciplinary quarrels to the courts. To be sure, hard data on this point remain elusive. Reporting of cases in Scotland has been sporadic at best; very few cases heard by Scottish courts and tribunals are considered worthy of reporting. In any event, much of the reporting has fallen far behind. ${ }^{265}$ In fact, a computer-based search of cases decided since 1950 revealed only seven Scottish cases (two implicating the same controversy) that reflected academic or disciplinary disputes between students and universities; ${ }^{266}$ in only four did a student directly challenge an academic decision. ${ }^{267}$

262. See also University of Strathclyde, Reg. 5 (Regulations for Student Discipline), $\S$ 5.1 .5 .

263. University of Aberdeen, Resolution No. 196 of 1996 (Code of Practice on Student Discipline), $\S \S 5.1,5.2$.

For the disciplinary procedures at other Scottish universities, see Code of Discipline, in Glasgow Calendar: Fees \& Information, supra note 182, at 38-42; Charter (SCHEdUle), STATUTE 18: Discipline, in DundeE Calendar, supra note 41, at 182; Ordinance 40: Discipline, in DUNDEE CALENDAR, supra note 41, at 198-210.

264. Dutile, supra note 4 , at $96-99$.

265. WHITE \& WILLOCH, supra note 8, at 212.

266. University of Aberdeen v. Dow, 1995 Sess. Cas. (Outer House, Nov. 22, 1995); Re Conor Reilly, 1995 Sess. Cas. (Outer House, Aug. 22, 1995); Re Alistair Joobeen's Application, 1995 S.L.T. (Notes) 120, 1994 Sess. Cas. (Outer House, July 28, 1994); Ahmed Saleh v. University of Dundee, 1994 Sess. Cas. (Inner House-Extra Division, June 8, 1994); Naik v. University of Stirling, 1994 S.L.T. 449, 1993 Sess. Cas. (Outer House, June 22, 1993); Re Elaine Parks Carlton, 1994 S.L.T. (Notes) 549, 1993 Sess. Cas. (Outer House, Sept. 24, 1993); Re Ahmed Saleh, 1992 Sess. Cas. (Outer House, Nov. 6, 1992). Indeed, the first of these, Dow, grew out of an academic dispute (the University failed Mr. Dow's thesis) but directly involved the lodging by the University and others of a petition and complaint averring a breach of interim and permanent interdicts entered against $\mathrm{Mr}$. Dow in connection with disruption and defamation. The court found Mr. Dow guilty of breaching both interdicts. University of Aberdeen v. Dow, 1995 Sess. Cas. (Outer House, Nov. 22, 1995).

267. Two of the other three involved primarily a dispute over the payment of fees. $\operatorname{Re}$ Alistair Joobeen's Application, 1995 S.L.T. (Notes) 120, 1994 Sess. Cas. (Outer House, July 28, 1994); Naik v. University of Stirling, 1994 S.L.T. 449, 1993 Sess. Cas. (Outer House, June 22,1993 ) (the court found judicial review appropriate and held for the student, noting 
Perhaps, in this connection, anecdotal evidence serves just as well to reflect the relative lack of litigation between students and Scottish universities regarding academic and disciplinary quarrels. At the University of Aberdeen, over the last twenty-five years, only one civil matter involving a student made it to the courts. ${ }^{268}$ In fact, the University has no general counsel. ${ }^{269}$ Perhaps as a harbinger, however, students there frequently threaten suit in dealing with the University. ${ }^{270}$

Officials at St. Andrews, with over 5,400 students, recall no litigation against the University, though "a few" students and one parent have threatened suit. Indeed, St. Andrews has no campus police and no University attorney. Although the fact that the current Clerk of the University Court is a lawyer may have played a role in the appointment, the position itself is not a legal position. ${ }^{271}$ No student in memory has sued the University of Edinburgh over an academic or disciplinary matter, and threats of suit are rare. The University employs no full-time attorney. ${ }^{272}$ Students at Glasgow, though over 16,000 strong, "very rarely" sue and rarely threaten suit; such threats would be met with a firm "Go ahead!"273 Strathclyde has not been sued "in at least five years." 274 The same absence of litigation characterizes other universities in Scotland. ${ }^{275}$ That there is no journal dedicated to the law of education in Scotland ${ }^{276}$ reflects in part the

that the attempted termination for nonpayment of fees may have been conduct-related, thus implicating the protections of the code of discipline, not just the regulations relating to fees). The third addressed a petition and complaint averring a breach of interim and permanent interdicts entered against a student. University of Aberdeen v. Dow, 1995 Sess. Cas. (Outer House, Nov. 22, 1995).

268. Powell Interview, supra note 47. Another Aberdeen official also remembered but one such court case. Webb Interview, supra note 163.

269. Webb Interview, supra note 163.

270. Powell Interview, supra note 47.

271. Clark \& Quinault Interview, supra note 66.

272. Rennie Interview, supra note 152.

273. Reynolds Interview, supra note 155.

274. Mellows Interview, supra note 6.

275. See, e.g., Farrington Interview, supra note 6 (no lawsuits in memory specifically regarding academic or disciplinary matters, although litigation there has involved the argument that failure to pay a fee was a disciplinary matter, not a contractual one, calling for a different procedure; University has no full-time counsel); and Parkinson Interview, supra note 6 (no such lawsuit in memory and no University counsel).

276. Of course, this lack is offset by publications relating to the law of education in the United Kingdom, which generally applies in Scotland. Farrington Interview, supra note 6. The United States publishes many journals dealing exclusively with the law of education; these range from the standard scholarly magazine to the newsletter. See, e.g., BYU EDUC. \& L.J. (Provo, Utah); J.C. \& U.L. (Notre Dame, Ind.); J.L. \& EDUC. (Columbia, S.C.); and ScH. L. Bull. (Chapel Hill, N.C.). To be sure, such publications reflect the larger U.S. population as well as litigation rates there. 
paucity of litigation there involving not only university students, but students at all levels.

Even allowing for the great differences in volumes of students, the rate of student litigation in the United States far exceeds that in Scotland. Students and litigation are not strangers in the United States; as one campus official confirmed, "We get sued all the time, or at least threatened with a suit. "277 In the fall of 1994, the United States had 14,278,790 students, ${ }^{278}$ compared with Scotland's 68,004. ${ }^{279}$ Case reporters from 1980 through 1996 contain at least 231 academic or disciplinary cases brought by students against American institutions of higher education. Indeed, this number undoubtedly understates the American student's willingness to sue. About twenty-three percent of American higher-education students-thirty-three percent if only four-year institutions are considered-attend private institutions. Since decisions of such institutions tend not to be "state action" under the U.S. Constitution, possible causes of action against them remain relatively limited. The two countries' relative disparity in recourse to a litigative remedy may more accurately be reflected in their levels of threats to sue, lawsuits filed but not pursued, settlements and the like; statistics regarding these matters, however, are still more elusive than reports on actual litigation. Even allowing for the small sample of cases in Scotland and the differing reporting practices in the two countries, the relative disinclination to sue among students in Scotland seems manifest not only from these data, but also from interviews with campus officials.

\section{B. The Reasons for the Paucity of Litigation Regarding University Decisions}

It is difficult, of course, to account fully for the fact that Scottish students, in the face of adverse academic and disciplinary decisions, sue much less readily than their American counterparts. Nonetheless, several reasons suggest themselves.

\section{Restrained Exercise of Jurisdiction and Sanctions by Universities}

Despite broadly and vaguely written definitions of misconduct, ${ }^{280}$ Scottish universities do not loosely exercise their jurisdiction over student matters and, even when they do, tend to keep sanctions minimal enough to avoid court action. Unlike many American universities, universities in

277. Freeman Interview, supra note 261.

278. Chron. Of Higher Educ.: Almanac Issue, Sept. 2, 1996, at 9. This figure reflects enrollment for the fall of 1994.

279. See supra text accompanying note 19.

280. See supra text accompanying notes $232-38$. 
Scotland feel little responsibility to exert moral influence over student conduct. The Zellick Report does not cite moral development as one of the bases for the exercise of university jurisdiction over student misbehavior. ${ }^{281}$ At Aberdeen, no "overt duty" of moral inculcation seems felt; because of the heavy moral influence of the church in the institution's history, no need to codify moral matters arose. Moreover, the University never adopted an in loco parentis regimen although, because of its smaller student population, it could be relatively more caring. ${ }^{282}$ At St. Andrews, moral inculcation, while not irrelevant, does not play an important role in the institution's mission; the principal purpose of dealing with student misconduct is to preserve order. Any former in loco parentis influences disappeared with the lowering of the age of majority to eighteen. ${ }^{283}$ Mission statements at Aberdeen, Edinburgh, Stirling, and Heriot-Watt make no mention of moral character or student conduct. ${ }^{284}$ This situation works side-by-side with a relatively new de-emphasis in the United Kingdom of disciplinary rules, constraints, and controls; institutions and students bring more concern to bear on what can, rather than on what cannot, be done. ${ }^{285}$

Indicative of Scottish universities' reticence to exert authority over student conduct is their attitude toward alleged conduct violating both university regulations and the criminal law. Perhaps the central issue confronted by the Zellick Report concerns the exercise of university jurisdiction when the student's alleged misconduct also constitutes a crime. The Zellick Committee notes four such situations that might justify an institution in investigating and deciding what action to take: 1) the conduct closely relates to the academic or other work of the university, for example damaging library books; 2 ) the conduct occurred on university property; 3 ) the conduct involved other university members; or 4) the conduct manifested none of these aspects. ${ }^{286}$ With regard to the first two, the Committee finds that the university is entitled, and in at least some cases will feel compelled, to take disciplinary action. The third, a "slightly less straightforward" one, presents adequate grounds for assertion of university jurisdiction, but the Committee urges careful thought regarding whether the interests of the university and its members call for disciplinary action in any individual case. ${ }^{287}$

281. See Zellick Report, supra note $217,13$.

282. Powell Interview, supra note 47.

283. Clark \& Quinault Interview, supra note 66.

284. See University of Aberdeen, Student Charter: Session 1995-96, at 1; UNIVERSITY OF EDINBURGH, FACTS AND FIGURES: 1995; STIRLING HANDBOOK, supra note 12, at 2; and Heriot-Watt University, Student Charter: Sources of Information, at 1.

285. FARRINGTON, supra note 17, at 22.

286. Zellick Report, supra note $217,96$.

287. See id. 17. 
The fourth situation presents the most difficulty. The only bases for the exercise of jurisdiction here would be a threat (or damage) to the university's good name, or concerns that the student allegedly involved endangers other members of the community or its good order (for example, by committing a sexual assault). The university's obligation to its members will require action whenever necessary to protect them from danger. Moreover, the university's failure to act could prompt serious criticism from students, parents, the press or others, especially if that failure occasions later incidents of misconduct. ${ }^{288}$

The Report urges special caution when the basis for disciplinary action lies only in the protection of the university's reputation, but it stops short of calling such action always unjustified. Student conduct that harms the university's relationship with the local community, for example offensive behavior affecting the neighbors of an off-campus student residence, offers an appropriate rationale for university action. Nonetheless, the institution should not invoke its disciplinary process merely to enforce contractual obligations of students to landlords or others. In all situations involving possible violations of the criminal law, in short, the university should proceed with great care. ${ }^{289}$

The Zellick Report suggests that the chief executive officer of the institution, or a delegate, be given the power early on to rule out campus proceedings. ${ }^{290}$ If the crime involved would not be serious, the committee sees no problem in proceeding with campus discipline; police, prosecutor, and court will have little interest in pursuing such situations. ${ }^{291}$ In Scotland, although police must report all offenses to the Procurator-Fiscal (the prosecutor), this official may send a warning letter or invite the alleged offender to pay a small fine as an alternative to prosecution. Moreover, conduct that is not serious to the police might be serious from a campus perspective-damaging a library book, for example. ${ }^{292}$

For serious offenses, however, the Report urges that universities defer campus proceedings-except temporary exclusion when the student presents imminent and serious danger to the community ${ }^{203}$ - until local authorities have acted. Indeed, internal action should not take place even if the complainant refuses to report the matter to, or cooperate with, local authorities. In no serious case, in short, should the university take action

288. Id.

289. See id. $917,8$.

290. See id. 19.

291. See id. 9 10. If local authorities do become involved, the institution may choose to await resolution of those proceedings, despite the long delay possible. Id.

292. Id. 1 1 10, 11.

293. For the committee's recommendations regarding suspension and exclusion pending prosecution, see $i d$. I $26-30$, and its model clause, id. at app. IV. 
prior to police investigation and prosecutorial consideration. If the prosecutor ultimately decides not to proceed with a case, only in exceptional cases should the university do so. ${ }^{294}$ Offenses of intermediate seriousness raise a presumption that campus authorities should not proceed with them before police and courts have done so. ${ }^{295}$

Once a criminal conviction takes place, the university may continue its own proceedings, with the criminal verdict accepted as far as relevant. The criminal penalty does not preclude imposition of a penalty by the university, though the university system should take into account the penalty imposed by the court system. The university should be especially careful about proceeding when the public prosecution resulted in acquittal. ${ }^{296}$

With regard to a somewhat overlapping category, off-campus misbehavior, the Zellick Report sets out no brief for comprehensive jurisdiction. The Report does concede, however, that exercise of extracampus jurisdiction by the university can be appropriate-for example, regarding conduct occurring on field trips, in other institutions to which the student had access by virtue of being a student at the university, or on work assignment. ${ }^{297}$

Scottish universities tend to share the Zellick Committee's apparent distaste for university jurisdiction over allegedly criminal or off-campus conduct. Aberdeen generally allows the criminal courts to address alleged conduct that constitutes a crime, even though neither the Zellick Report nor institutional rules preclude the possibility of campus charges in such cases. ${ }^{298}$ Aberdeen's provision requiring that serious matters normally be reported to, and that complainants cooperate with, the police prior to any internal action surely suggests the University's preference for outside disposition of such cases. So, too, does the mandate that, "insofar as it is relevant," the University accept the verdict of any court proceedings. ${ }^{299}$

St. Andrews also adheres to the Zellick recommendations. The University notifies the police of any drug situations, though virtually all of these have been minor ones. Still, the more contacts an off-campus matter has to the institution, the more likely the institution itself will bring charges. Officials there recognize the public's ambivalence on this issue: The

294. Id. I 12-15. In Scotland, university officials may not be able to learn why local authorities failed to prosecute; the Procurators Fiscal may not disclose such information. Id. 115.

295. Id. \ 16. For the Zellick Report's discussion of whether university officials should report misconduct to the police, see $i d$. I 17-25.

296. Id. I 31-33. For more on university proceedings following public trial, see id.

297. Id. If $40,41$.

298. Powell Interview, supra note 47. See University of Aberdeen, Resolution No. 196 of 1996 (Code of Practice on Student Discipline), $\$ \S 1.1 .11,1.2,1.3,1.3 .1,1.3 .2,6.1$.

299. University of Aberdeen, Resolution No. 196 of 1996 (Code of Practice on Student Discipline), § 1.3.2. 
institution came to rely on police treatment of criminal-type allegations because the public thought internal treatment unduly favored students. Faced with noisy student neighbors, however, citizens complain when the University deems the matter a police problem. As a result, the University may begin to take a greater interest in off-campus student disruption or vandalism. ${ }^{300}$ In any event, the disciplinary code precludes University charges regarding any matter successfully defended in a court of law. Internal proceedings may follow a guilty verdict in a court of law, but only to decide the student's fitness to continue as a member of the University community or as a resident in University housing. ${ }^{301}$

Edinburgh claims no off-campus jurisdiction; any situation serious enough should be reported to the police. Moreover, the University avoids "double jeopardy," that is, taking action in addition to that of local authorities. ${ }^{302}$ Its disciplinary code specifies that there is generally "no reason why a student's appearance in a criminal court should be followed by disciplinary proceedings." ${ }^{303}$ Despite its adherence to the Zellick principles, the University might take action if faced with real danger, such as a harddrug sale or sexual assault, especially if the situation had several University "contacts" (for example, if both the alleged perpetrator and victim were members of the University community). ${ }^{304}$ Glasgow takes notice of even offcampus conduct that reflects on the University. Nonetheless, with regard to alleged criminal conduct, campus officials await the result of civil proceedings before deciding whether to take action; neither acquittal nor conviction bars University charges. ${ }^{305}$

At Stirling, pursuant to the Zellick guidelines, the one or two serious cases arising each year go to the police. Although a serious threat would cause the University to act before the courts, generally campus charges would be brought, if at all, only after any judicial proceedings. ${ }^{306}$ Strathclyde, which adheres to the Zellick Report "not because it's written, but because it makes sense," would take action early in a seriously threatening situation despite the possibility of action in the courts. ${ }^{307}$ HeriotWatt, which modeled its code on the Zellick Report, steers clear of any incident in which the police are involved unless the University community

300. Clark \& Quinault Interview, supra note 66.

301. University of St. Andrews, Resolution of the University Court 1992 No. 4, § 4(b) and (c).

302. Rennie Interview, supra note 152.

303. University of Edinburgh, General Statement on University Discipline (undated).

304. Rennie Interview, supra note 152.

305. Reynolds Interview, supra note 155.

306. Farrington Interview, supra note 6.

307. Mellows Interview, supra note 6. 
is threatened. ${ }^{308}$ The University of Dundee asserts a fairly broad reach, stating that all students are subject to its disciplinary jurisdiction regarding conduct "both on and off University property." 309

By way of comparison, the University of Michigan claims possible jurisdiction over conduct 1) that violates state or federal law when the conduct has "serious impact" on the University community; or 2) that takes place in Ann Arbor, its municipal site, and even beyond Ann Arbor if the behavior "poses an obvious and serious threat or harm to the University community." ${ }^{210}$ Ongoing criminal or civil proceedings will put off campus proceedings relating to the same conduct only if the accused student accepts suspension from the University. ${ }^{311}$ Indiana University does not await action by the court. It addresses not only on-campus situations, but most likely even an off-campus sexual assault if it comes to the attention of campus authorities. When the alleged conduct also constitutes a crime, the campus authorities try to accommodate the request of a student's lawyer to await the trial's outcome. Nonetheless, if danger to the community is involved, the campus process addresses the situation without delay. ${ }^{312}$

The data seem to bear out the relatively rare exercise by Scottish universities of authority over student misconduct, whether the rarity stems from university reticence, better student behavior, ${ }^{313}$ student reluctance to pursue remedies such as appeals, or, as seems likely, a combination of these. At Aberdeen, with its 9,650 students, only sixteen "academic disciplinary" cases went to a hearing during the 1995-96 academic year; in only ten of these were the allegations upheld. ${ }^{314}$ Only one of these went beyond a oneperson disposition to an appeal before the disciplinary committee. ${ }^{315}$ At St. Andrews, with over 5,700 students-about 3,000 of whom reside in campus housing, ${ }^{316}$ no case has gone to the discipline committee in at least two years. Most misconduct has been minor and alcohol-related. ${ }^{317}$ Usually, "wardens"

308. Parkinson Interview, supra note 6.

309. Ordinance 40: Student Discipline $\S 2$, in DUNDEE CALENDAR, supra note 41 , at 198.

310. University of Michigan, Code of Student Conduct (1996).

311. Id.

312. Freeman Interview, supra note 261.

313. Interestingly, St. Andrews-like, apparently, most other Scottish universities-has no true campus-security force, although it retains a private security firm for nighttime protection of its property. Clark \& Quinault Interview, supra note 66.

314. Letter from Trevor Webb, Deputy Academic Registrar, Univ. of Aberdeen, to the author (June 12, 1997) [hereinafter Webb Letter] (on file with author).

315. Webb Interview, supra note 163.

316. UNIVERSITY OF ST. ANDREWS, PROSPECTUS 1996 ENTRY, at 35, 37.

317. Student unions in the United Kingdom took in 44 million British pounds (about $\$ 66$ million) through sales of alcohol during the 1994-95 academic year, despite relatively low prices. David Charter, $144 m$ Bar Bill of Student Drinkers Who Won't Go Far, TIMES (London), July 22, 1996, at 3. 
in the residence halls dispose of such matters through the use of fines. Perhaps twenty to thirty cases a year go beyond the residence halls, most on appeal to the Hebdomadar. Cheating cases are rare, with very few going to a disciplinary committee. ${ }^{318}$

At Edinburgh, with over 15,000 students, the disciplinary committee has not conducted a hearing for over three-and-one-half years. Cheating cases are "outstandingly rare." ${ }^{319}$ At Glasgow, with over 16,000 students, only one case goes to the disciplinary board in a two- or three-year period. ${ }^{320}$ At Stirling, with 5,200 students and 3,030 University-owned or leased housing units, ${ }^{321}$ no case has gone to the Serious Offenses Board in over five years; ninety-five percent of the fifty or sixty disciplinary cases a year relate to alcohol, and most go to summary procedures to be met with warnings or fines. The half-dozen cheating cases that arise annually get resolved by examiners through grade reduction or loss of credit. ${ }^{322}$ The disciplinary committee at Heriot-Watt, which has 4,500 full-time students on its campus and another 4,500 at three affiliated campuses, saw slightly more action than its counterparts at most Scottish universities-four or five cases in the last two years. Only two alcohol-related cases have gone to the committee in the last five years, but presumably "wardens" dispose of many such cases at the student-housing level. Two student appeals have gone to the University court in the last year. ${ }^{323}$

Strathclyde, where cheating is the "most popular" offense, has used its top-level disciplinary procedure (a one-person decision-maker) but once in five years. ${ }^{324}$ Proceedings before the University's discipline committee, for which good data are available, provide a good picture of the disciplinary situation there. From June 1968 through June 1996, fifty-two matters, some of which involved more than one student and five of which involved appeals from lower levels, came before that committee. This represents an average of 1.9 cases per year. ${ }^{325}$ Of these fifty-two alleged violations, twenty-nine (fifty-six percent) involved academic dishonesty, nine involved disorderly conduct or alcohol, four involved misuse of computers, three involved

318. Clark \& Quinault Interview, supra note 66.

319. Rennie Interview, supra note 152.

320. Reynolds Interview, supra note 155.

321. STIRLING HANDBOOK, supra note 12 , at 18.

322. Farrington Interview, supra note 6. Even the Minor Offenses Board has not met in a year. Id.

323. Parkinson Interview, supra note 6.

324. Mellows Interview, supra note 6.

325. Letter from Susan Mellows, Academic Registrar of the Univ. of Strathclyde, to the author (July 26, 1996) [hereinafter Mellows Letter] (on file with author). The trend is moderately upward: from June 1982 through June 1996, thirty-six cases (or 2.6 per year) came before the committee. See id. 
library offenses, and the rest a potpourri of miscreance. ${ }^{326}$ Although differences in populations, procedures, and availability of data make comparisons difficult, these numbers make those at representative American universities seem robust, indeed..$^{327}$

On the academic side, statistics are less complete. Nonetheless, we know that students tend to disagree with the university more often regarding academic decisions than regarding disciplinary ones. This seems natural, of course, since, unlike disciplinary decisions, academic decisions emanate regarding all students; there is simply more to disagree with on the academic side. In the Engineering Faculty at Strathclyde, for academic years 1993 through 1995, approximately 5,550 academic "decisions"328 spawned 120 appeals. In the five-year period from 1990 through 1995, the Arts and Social Sciences Faculty found 193 of its academic decisions appealed. ${ }^{329}$

326. Id.

327. At the University of Michigan, from January 1, 1993, to April 1, 1995, a total of 434 "contacts and inquiries" were reviewed by the Judicial Advisor. No action was undertaken regarding 134 of these. In 97, the complaint was referred to other University units; in 16, after consultation with the Judicial Advisor, the complainant decided not to file a complaint; in 59, a "substance abuse warning letter" was sent; and in 128 , the Office of the Judicial Advisor formally investigated. There were 203 allegations of misconduct in these 128 cases, including 31 allegations of "harassment"; 29 allegations of "unauthorized taking or possessing of property/services"; and 27 allegations of "physical assault, battery or endangerment."

Ultimately, 150 violations were charged (46 alleged violations were dropped during the investigation and 7 remained under investigation). Of the 150 violations charged, 75 yielded a finding of "responsible"; 28 yielded a finding of "not responsible"; and 26 were mediated (21 charged violations were yet unresolved). University of Michigan, Summary of Judicial Activity: Statement of Student Rights and Responsibilities (Jan. 1, 1993 to Apr. 1, 1995).

At Indiana University, during the 1994-95 academic year, 2497 cases of personal misconduct were processed through the campus judicial system. These cases represented 3183 alleged violations of the Code of Student Ethics (some cases involved more than one such violation-for example disorderly conduct and assault). (There were 2022 alleged "Residence Hall Handbook Violations.") Sixty of these 2497 cases ended up before a Hearing Commission (all others reached final resolution in other fora).

Of the 3183 violations, the greatest number, 1107 , involved "alcohol." In second place, with 393 violations, are "actions which endanger." In third place, with 357 violations, is "failure to comply."

Interestingly, there were no cases of racial or sexual harassment. There were 144 cases of "dishonest conduct"; 46 cases of "physical abuse"; 131 cases of "unauthorized possession of drugs"; and 208 "violations of any Indiana/Federal Criminal Law." Indiana University, 1994-95 Comparative Report on Personal Misconduct by Academic Year.

During the 1994-95 academic year, Indiana University processed 68 cases of academic misconduct, reflecting 83 instances: cheating (43); plagiarism (24); and other academic dishonesty (16). Id.

328. "Final grade/award" and "progress decisions." Mellows Letter, supra note 325.

329. Id. 
From all this, we see that Scottish universities address relatively few disciplinary and academic disputes and resolve at relatively low levels of the hierarchy those disputes they do address. This principle of subsidiarity manifests itself often, in documents and interviews, at Scottish universities. ${ }^{330}$ At times, a violator may be formally summoned before a high university official and merely given an intimidating warning. ${ }^{331}$ Also, disciplinary boards are sometimes reluctant to convict. ${ }^{332}$ Moreover, the evidence suggests that these universities treat relatively leniently those cases ultimately resolved against the student. Meaningful statistics are hard to come by, either because records are not kept or not divulged, or because the numbers at a particular institution are so small as to be unrevealing.

A look at Strathclyde's profile nonetheless suggests that litigation in Scotland remains relatively unused by students in part due to the low sanctions imposed, sanctions that provide little incentive to sue. Of the nineteen allegations of academic dishonesty coming before the discipline committee between June 1982 and June $1996,{ }^{333}$ only one resulted in a student's expulsion; another yielded the revocation of a degree; and still another resulted in a one-year suspension (coupled with a discounting of the "exam diet"). Four cases were effectively dismissed for lack of evidence (though in two of these the student still earned a warning). In two others the student's examination attempt was voided, and in eight others the student was given a reprimand plus some discounting of academic work. Two additional reprimanded students received other academic penalties-one the voiding of an "honours attempt" with no allowance of a "resit"; the other a voiding of the examination coupled with the loss of one class of "honours" in the final "honours" classification. A sampling of other cases reveals reprimands for assault, for transmitting offensive pictures through the computer system, for drunkenness on a field trip, and for drunk and disorderly conduct. Expulsion did attach to a serious computer offense and expulsion from a residence hall due to the triggering of a false fire alarm. ${ }^{334}$ Nonetheless, these results, overall, fall far short of the draconian and, for that reason, seem generally unlikely to prompt litigation. ${ }^{335}$

330. See, e.g., Heriot-Watt University, Student Charter: Sources of Information 4 (undated); Powell Interview, supra note 47; Rennie Interview, supra note 152; and Mellows Interview, supra note 6.

331. At Edinburgh, this process is called "carpeting." Rennie Interview, supra note 152.

332. Mellows Interview, supra note 6.

333. The penalties for the cases coming before the committee from 1968 though 1982 are not available.

334. Mellows Letter, supra note 325.

335. At the University of Michigan, sanctions imposed in 89 cases, by either a student panel hearing or an administrative hearing officer, included 28 "community services"; 27 "restitution"; 14 "class attendance"; 3 "suspension from the University"; and 2 "expulsion" (one of which was reduced, on appeal, to "suspension"). University of Michigan, Summary 


\section{Students' Ample Access to Information and Extra-judicial Redress}

Clearly among the reasons for the relative lack of litigation by students against universities are the generous internal procedures of these institutions. ${ }^{336}$ These procedures provide students who have real or potential grievances against universities with both information and wide avenues of redress. We have already seen the procedures generally applicable in Scottish universities to such students, procedures replete with protections, including access to layers of appeals.

Clearly, Scottish universities make both the academic and personal welfare of their students an important commitment. ${ }^{337}$ Officials at St. Andrews, for example, unabashedly allude to their "caring university. ${ }^{n 338}$ In addition, user-friendly universities find strong encouragement from the government itself. As part of a broad "citizen's charter" movement in the United Kingdom, ${ }^{339}$ the Education Department of the Scottish Office issued The Further and Higher Education Charter for Scotland. This document essentially sets out a "students' bill of rights." The Charter treats students largely as consumers, ${ }^{340}$ even though it avoids the explicit consumer language

of Judicial Activity: Statement of Student Rights and Responsibilities (Jan. 1, 1993 to Apr. 1, 1995).

At Indiana University, where all 2497 cases were processed through the campus judicial system, the disposition included 527 "not responsible"; 46 "administrative error dismissal"; 717 "reprimand and warning"; 757 "disciplinary probation"; 108 "restitution"; 4 "expulsion from University housing"; 24 "suspension from the University"; and 2 "expulsion from the University." Indiana University, 1994-95 Comparative Report on Personal Misconduct by Academic Year.

336. Though to a different extent, the procedures at Indiana University also manifest a "student-friendly" approach. The disciplinary set-up, for example, appears in a statement that stresses rights as well as responsibilities. See Indiana University, Code of Student Ethics, Part I (1995). The procedures for determining violations and sanctions were "designed to provide students with the guarantees of due process and procedural fairness. ..." Id. at Part IV.

337. 2 COMMONWEALTH UNIVERSITIES YEARBOOK, supra note 13, at 1294.

338. Clark \& Quinault Interview, supra note 66.

339. See British Prime Minister John Major's Citizens' Charter Initiative-Raising the Standard, CM 1599, July 22, 1991. The Initiative spawned "some forty Charters, broad statements of what citizens can expect, in the public sector and privatized utilities governing standards of service in such varied areas as prisons, hospitals, railways, law courts, schools and universities." Farrington, supra note 15, at 1 n.2. See also FARRINGTON, supra note 17, at 31 .

340. See Ian Lang, Foreword to THE FURTHER AND Higher EDUCATION CHARTER FOR SCOTLAND 2: "This Charter sets out what you-as a current or prospective student . . . can reasonably expect of colleges and universities as providers of education and training; and what you can do if you are dissatisfied."

It has been noted that the student status of consumer may be difficult to reconcile with the increased student representation in governance conceded by the universities during the $1960 \mathrm{~s}$ and 1970s. FARRINGTON, supra note 17, at 366. 
found in the Charter for Higher Education in England. ${ }^{341}$ The Charter, which clearly contemplates the development of individual university charters based on its principles, sets a framework for the "standards of service" that students can expect from universities, including access to information and avenues of complaint. ${ }^{342}$ The Charter tells students they may expect courteous and prompt handling of their enquiries, efficient and appropriate assessment procedures, thorough and timely investigation of their formal complaints, information concerning student representation on course and other committees, information regarding student participation in academic decision-making and institutional management, and information on the institution's academic regulations and disciplinary procedures. ${ }^{343}$ The right to object to an academic decision should be formally set out in the institution's academic-appeals procedure. ${ }^{344}$

This national Charter has received mixed reviews. ${ }^{345}$ As it contemplated, individual universities, including Aberdeen, have adopted their own charters, codes of practice, or other expressions of intent concerning their standards of service. ${ }^{346}$ These pursue the principles outlined in the parent Charter. To both applicants for admission and matriculated students, Aberdeen's charter provides a guide to the University's services and to information about them. It informs students specifically how to appeal adverse academic decisions. It informs students as well about the services provided by the Students' Representative Council (SRC), about making views known to the University, and about how to contact the Rector or the Rector's Assessor. ${ }^{347}$ At Heriot-Watt, the student charter specifies the University's interest in settling "complaints promptly, fairly, courteously and as near as possible to the point of origin. ${ }^{\text {"34 }}$ Strathclyde sensed itself already in compliance with the national Charter's prescriptions, save for informing students how to pursue complaints; a simple sheet did the trick. ${ }^{349}$ Some university officials consider student charters "political claptrap" and look to other avenues, like the traditional student handbook, to address many of the same concerns. ${ }^{350}$

Students' feelings of ownership with regard to the institution undoubtedly stem in part from their wide participation in its governance. At

341. See FARRINGTON, supra note 17 , at 320 .

342. Id. at 4, 5, 20.

343. Id. at 5,16 .

344. Id. at 20.

345. "It has not had great impact here." Reynolds Interview, supra note 155.

346. See FARRINGTON, supra note 17, at 320.

347. See University of Aberdeen, Student Charter: Session 1995-96.

348. Heriot-Watt University, Student Charter: Sources of Information, at 4 (undated).

349. Mellows Interview, supra note 6. See University of Strathclyde, Student Complaints (1995).

350. Clark \& Quinault Interview, supra note 66. 
Aberdeen, the students alone elect the Rector, the chair of the Court, and one of the three senior officials at the University. The Court includes not only the Rector, but the Rector's Assessor ${ }^{351}$ and the President of the SRC. ${ }^{352}$ Aberdeen's Senate includes nine student members. ${ }^{353}$ The Regent at Aberdeen has special responsibilities toward students. ${ }^{354}$ An active SRC, first constituted in 1854 and recognized by Parliament five years later, boasts a position constitutionally established within the framework of the University. The SRC promotes the interests of the students and affords a "recognized means of communication between students and the university authorities." 355 The SRC sends representatives to many university committees. ${ }^{356}$ Often, in disputes with the University, students will seek representation from the SRC. ${ }^{357}$ Two students sit on the disciplinary

351. See The UNIVERSITIES (SCOTLAND) ACT 1889, § 5: “The Rector may, before he appoints his Assessor, confer with the Students' Representative Council." At St. Andrews, the Rector's Assessor, also a member of the Court, "is usually a student." UNIVERSITY OF ST. ANDREWS, PROSPECTUS 1996 ENTRY, at 6.

352. At Edinburgh, the Court includes, besides the Rector and the Rector's Assessor, "two fully matriculated students nominated by the Students' Representative Council." History and Constitution, in EDINBURGH CALENDAR, supra note 40, at A-23. At Heriot-Watt, the Court includes three from the Graduates' Association of the University, the Honorary President of the Students' Association, the President of the Students' Association, and one member of the Council of Students' Association. CHARTER OF HERIOT-WATT UNIVERSITY (SCHEDULE), STATUTE XII, $\S 1$ (ix)-(xi). For the membership of university Courts generally, see supra text accompanying notes $42-47$.

353. At Edinburgh, thirteen student associate members populate the Senate. History and Constitution, in EDINBURGH CALENDAR, supra note 40, at A-24. Heriot-Watt's Senate includes the President of the Students' Association and two members of the Council of the Students' Association. Charter of Heriot-WaTt UNIVERSITY (SCHEDULE), STATUTE XIII, $\S 1$ (ix). For the membership of university Senates generally, see supra notes 88-90.

354. Webb Interview, supra note 163.

355. ABERDEEN Calendar, supra note 47 , at 32-33. See The UNIVERSITIES (SCOTLAND) ACT 1889, §§ 5, 14(12). At St. Andrews, the Students' Association, the umbrella group for the SRC and the Students' Council, "acts like a Visitor" for the students. Clark \& Quinault Interview, supra note 66.

Student unions first organized in Scotland as Student Representative Councils, earning statutory recognition in the Universities (Scotland) Act of 1889. See supra note 351 . Universities founded later have student associations created by charter or by university statute. Students automatically become members of the student union through either an express or implied term of the contract of matriculation. In the early $1990 \mathrm{~s}$, the government expressed its intention to make student unions voluntary. FARRINGTON, supra note 17, at 185-87, 192. See generally id. at 185-88, 192.

356. ABERDEEN CALENDAR, supra note 47, at 33.

357. David Strachan, Voices From Three Generations, in ABERDEEN UNIVERSITY 194581: Regional Roles AND NATIONAL NEEDS, supra note 51, at 90 . At times, the SRC President will represent students. Webb Interview, supra note 163.

At St. Andrews, the Welfare Advisor for the Students' Association deals with University officials regarding individual cases and does so responsibly and positively. Clark \& Quinault Interview, supra note 66. 
committees. ${ }^{358}$ At hearings before a disciplinary committee, the charged student receives significant discovery and may be accompanied by any person of his choice. The student may address questions to the Convener of the committee or to any witnesses, and may also make a concluding statement. ${ }^{359}$

Other examples of university openness to students abound. At HeriotWatt, every department has a staff-student committee for the discussion of proposed developments and other student concerns. ${ }^{360}$ At Stirling, all committees dealing with student welfare or living conditions must include members of the Students' Association. ${ }^{361}$ Students serve on the Planning and Resources Committee, which exercises the main responsibility for allocating resources and for advising the Court on financial matters, as well as on "most committees relating to teaching activity, or the management, of the University." ${ }^{362}$ Stirling assigns to each student an Adviser of Studies, whose duties-specified in writing-include "assist[ing] in preparing a case for submission to University authorities." all disciplinary hearings must accord with principles of natural justice, the British equivalent of due process. ${ }^{364}$ In serious disciplinary cases at Edinburgh, if the University proceeds through a practicing advocate or solicitor, it provides the student with reasonable funds for similar representation. ${ }^{365}$ At Dundee, unless the accused objects, student "auditors" must be present at all disciplinary proceedings before an Authorized

358. University of Aberdeen, Resolution No. 196 of 1996 (Code of Practice on Student Discipline), § 8.1. Student membership on such committees is common. At Edinburgh, for example, six of the twelve members of the Standing Commission on Discipline, six of the twelve members of the Discipline Committee, and at least four members of any hearing panel, are students. See University of Edinburgh, Code of Student Discipline $\$ \S 1(a), 3(a)(1)$ and (iv). For the membership of such committees at other universities, see supra note 249 . At Heriot-Watt, students sit on the University Court, on the Senate, and on several committees. Heriot-Watt University, Student Charter: Sources of Information, at 12 (undated).

Such representation may sometimes be more important symbolically than substantively; at one University, at least, student committee members seem more willing to "convict" than academic staff members. Mellows Interview, supra note 6.

359. University of Aberdeen, Resolution No. 196 of 1996 (Code of Practice on Student Discipline), $\S \S 13.2,13.2 .4,13.2 .5$.

360. Heriot-Watt University, Student Charter: Sources of Information, at 12 (undated).

361. Charter (SECond Schedule), Statute 12, § 1, in Stirling Calendar, supra note 41 , at 80 .

362. STIRLING HANDBOOK, supra note 12, at 3.

363. Id. at 9 .

364. Ordinance 2: Code of Student Discipline, Natural Justice § 1.3, in STIRLING CALENDAR, supra note 41 , at 112 . Officials at Strathclyde adhere to the principles of natural justice, taken to mean hearing the student and providing a neutral decision-maker. Mellows Interview, supra note 6.

365. See University of Edinburgh, Code of Student Discipline § 5(a)(ii). 
Officer. ${ }^{366}$ At Edinburgh, the SRC employs two or more permanent staff to help students and to advise on appeals. Sometimes these employees carry more credibility with students than do officials of the university. In certain cases, as a result, such employees might temper a student's anger, preclude an appeal, or otherwise help resolve matters at a low level. ${ }^{367}$ Dundee students, both current and former, have a general right of access, as well as a process for correction, with regard to all personal information kept by the University ${ }^{368}$ The provisions applying to students in Educational Studies at Stirling reflect the kind of care and, in fact, leniency with which Scottish institutions address academic progress. The Board of the School of Human Sciences may permit a candidate who was unable to complete the first semester of the program to begin anew. ${ }^{369}$ A candidate failing a unit of instruction must be granted the opportunity to submit "a further piece of assessed work or to undertake a repeat examination," a process available for up to four units of work; on these occasions, a student may not be given a grade lower than initially received. ${ }^{370}$ A project report or "Honours dissertation" found unsatisfactory may be referred to the candidate for resubmission. ${ }^{371}$ An honours candidate not fully successful may receive a general degree, ${ }^{372}$ and a candidate who was required to withdraw from the University may have the case reconsidered. ${ }^{373}$ Further, the Academic Council may waive any of the academic requirements set out in the governing ordinance..$^{374}$ At Glasgow, a student may have illness or "other personal circumstance" considered in the assessment of performance during an examination. ${ }^{375}$ Also at Glasgow, students in the Faculty of Arts subject to suspension or exclusion are informed in writing of the time and place at which the Progress Committee will consider their cases. These students are

366. See Ordinance 40: Student Discipline $\$ 8(3)$, in DUNDEE CALENDAR, supra note 41 , at 201.

367. Rennie Interview, supra note 152.

368. Ordinance 46: Student Access to Personal Information $\S \S 1,8$, in DUNDEE CALENDAR, supra note 41, at 216-17.

369. Ordinance 29: Degree of Bachelor of/Diploma in Educational Studies § D3, in STIRLING CALENDAR, supra note 41 , at 142.

370. Id. $\S \S \mathrm{E} 6, \mathrm{E} 7$.

371. 1d. \& E9.1, in STIRLING CALENDAR, supra note 41 , at 143.

372. Id. § E9.1.2; see also Faculty of Social Sciences § 21, in GLASGOW CALENDAR: FEES \& INFORMATION, supra note 182, at 120-21; and STIRLING HANDBOOK, supra note 12, at 6.

373. Ordinance 29: Degree of Bachelor of/Diploma in Educational Studies § E11, in STIRLING CALENDAR, supra note 41 , at 143.

374. Id. § F1.

375. Glasgow CAlENDAR: Fees \& InFormation, supra note 182, at 19. See also Code of Procedure for Appeals to a Faculty Appeals Committee § 3(a), in GLASGOW CALENDAR: FEES \& INFORMATION, supra note 182, at 22; and Code for Degree Examinations $\S \S 10,26$, 29, 42, in Glasgow CALENDAR: FEes \& INFORMATION, supra note 182, at 31, 33, 35. 
entitled to appear in person before the Committee or to make written representations. Students ultimately suspended or excluded may appeal to the Faculty Appeals Committee. Even those students whose suspensions are upheld are entitled to readmission as long as, within the next two examination periods, they make good their shortcomings. ${ }^{376}$

Is the university responsive to student concerns? Aberdeen's Regent, like many other officials at Scottish universities, feels strongly that disputes should be resolved internally and at the lowest administrative level possible. ${ }^{377}$ This philosophy seems clearly reflected in the frequency of success enjoyed by Aberdeen students appealing academic matters. Of the 174 academic appeals involving undergraduates at Aberdeen during the 1995-96 academic year, ninety-or approximately fifty-two percent were upheld; ${ }^{378}$ of the fourteen postgraduate academic appeals at Aberdeen during that academic year, five-or approximately thirty-six percent were upheld. ${ }^{379}$ Statistics for the three academic years 1992 through 1995 show that students succeeded in eighteen of thirty-four appeals-a stunning fifty-three percent-brought before the Senate Academic Appeals Committee. ${ }^{380}$ At the University of Strathclyde, during the two academic years 1993 through 1995, 120 appeals were taken from academic decisions within the Engineering Faculty. Of these, only thirty-three were fully rejected; eighty-seven garnered some kind of positive response. ${ }^{381}$ At Heriot-Watt, two appeals were taken to the Court during the 1995-96 academic year; in one, the degree was upgraded, in the other no decision has been made. ${ }^{382}$ The extent to which academic decisions get a new look outside the department or school in Scottish universities would surely surprise most American academics. ${ }^{383}$

376. Faculty of Arts $\S 11(\mathrm{~g})$ and (h), in GLASGOW CALENDAR: FEES \& INFORMATION, supra note 182 , at 60 .

377. Powell Interview, supra note 47.

378. Webb Letter, supra note 314 . These comprised a) appeals against a decision of the Examiners (in the nine cases upheld, the decisions resulted from the Examiners revising their original decisions in light of evidence presented on appeal-an Appeal Committee "does not have the power to overturn an academic decision of the Examiners"); b) appeals to a Students' Progress Committee for permission to continue despite failure to satisfy normal progress requirements; and c) appeals against the decision of a Head of Department or of a Students' Progress Committee disallowing progression to the "next normal year/level of study." Id.

379. Id. Each of these appeals challenged a decision of the Examiners. Id.

380. Memorandum from David M. Jones, Deputy Clerk to Senate and Clerk to Boards of Studies in Science and Medicine, Univ. of Aberdeen, to the author (July 29, 1996) (on file with author).

381. Mellows letter, supra note 325. Interestingly, however, the number of appeals from the first of these academic years to the second rose from 31 to 89 , an increase of $187 \%$. Id.

382. Parkinson Interview, supra note 6.

383. For example, in 26 years as a member of the faculty at the University of Notre Dame, the author can recall no instance in which an academic decision made by the law school regarding one of its students was reversed outside the school. 
One of the most knowledgeable observers of the academic scene in the United Kingdom has noted that most academic and disciplinary disputes there "are resolved internally . . . ." The high costs befalling universities that find themselves in court reinforce the incentives to reach such resolutions. ${ }^{385}$

Still, more could be done to shelter higher education from the prospective intrusion of the civil courts. There is, for example, no use of ombudsmen in the resolution of academic or disciplinary disputes. ${ }^{386}$ Of course, the use of Visitors, as in England and Australia, projects at least a surface attractiveness. Relatively informal, private, cheap, and fast, such an approach can represent a "useful instrument of social policy in the context of university administration and academic discipline." 387 Accordingly, "suspicion of [its] archaic origins . . . should not inform current attitudes to the visitatorial jurisdiction." 388 Nonetheless, some officials at Scottish universities deem even it too adversarial, complex, and expensive. ${ }^{389}$ Some officials feel that the extensive internal procedures at Scottish universities make unnecessary both the ombudsman and the Visitor. ${ }^{390}$ Still, some of the newer universities in the United Kingdom, and at least one in Scotland, have used independent arbiters-a close parallel to the concept of a Visitor. ${ }^{391}$ Discussions at St. Andrews have addressed the possibility of appointing an

384. Farrington, supra note 15, at 10. Appeals in American universities, at least in disciplinary cases, may also be well received. At the University of Michigan, the Appeals Board reviewed two cases in a 15 month period. Although in one case it upheld a sanction of suspension from the university, in the other it reduced a sanction of expulsion to one of suspension. University of Michigan, Summary of Judicial Activity: Statement of Student Rights and Responsibilities (Jan. 1, 1993 to Apr. 1, 1995). At Indiana University, during the 1994-95 academic year, 60 of the 2497 cases processed through the campus judicial system were ultimately reviewed by a hearing commission. In 38 of those cases, the hearing commission reversed the original decision or imposed a weaker sanction. (It upheld the original decision in 10 of the cases and imposed stronger sanctions in the remaining 12.) Six cases were ultimately reviewed by a Review Board. In all six cases, the original finding of responsibility was upheld, but in two the sanction was lessened. Indiana University, 1994-95 Comparative Report on Personal Misconduct by Academic Year. In light of the large number of cases processed, however, these figures reflect a relatively low reversal rate.

385. Farrington Interview, supra note 6. See infra text accompanying notes 457-69.

386. See, e.g., Rennie Interview, supra note 152; and Mellows Interview, supra note 6. Neither the Parliamentary Commissioner nor its local equivalent deals with university disputes. Farrington Interview, supra note 6. See PARLIAMENTARY COMMISSIONER ACT 1967 (SCHEDULE 2).

387. G. L. Peiris, Visitatorial Jurisdiction: The Changing Outlook on an Exclusive Regime, 16 ANGLO-AM. L. REV. 376, 403 (1987).

388. Id. at 406.

389. Mellows Interview, supra note 6 ("You begin with someone who knows nothing about the University").

390. Reynolds Interview, supra note 155.

391. Farrington Interview, supra note 6. 
independent person to handle appeals. ${ }^{392}$ Dennis Farrington, an expert on the Scottish law of education, has urged some form of compulsory arbitration. The arbiter would be an independent person with a status like the English Visitor, an office unknown-at least in modern times-to Scottish institutions. ${ }^{393}$ Farrington argues that the student-charter initiative and government proposals for providing students access to external review of certain complaints point toward such a development. ${ }^{394}$ Under his proposal, all disputes would be settled using ordinary contractual principles. Such a procedure would grant students access to a neutral decision-maker, provide them with reasons for the decision, preserve the funds of both universities and legal-aid providers, and prevent cases from reaching the courts. ${ }^{395}$

Perhaps the Rector could become the ideal arbiter-close enough to the university to know it well, distant enough to provide neutrality and perspective, and prestigious enough among the students to lend rectorial decisions appropriate persuasiveness and weight. At St. Andrews, for example, students have called on the Rector for help with regard to their individual cases. ${ }^{396}$

\section{The Culture and Other Factors}

When asked why Scottish students so rarely call on courts to challenge university decisions, officials virtually unanimously invoke, among other things, "the culture." 397 British education traditionally has been elitist-though more egalitarian in Scotland than in England. Moreover, education was free; accordingly, students felt privileged to be at the university and took "whatever came." 398 When disputes have resulted in adverse determinations before internal bodies, students in Scotland have remained far readier than American students to accept the outcome. Moreover, Scottish students have tended to see the legal profession as designed only for service involving the rich or the criminal process-not academic or disciplinary matters. ${ }^{399}$

392. Clark \& Quinault Interview, supra note 66.

393. FARRINGTON, supra note 17, at 51-52.

394. Id. at 52.

395. Farrington, supra note 15, at 21 . See also FARRINGTON, supra note 17 , at 44 .

396. Clark \& Quinault Interview, supra note 66.

397. Powell Interview, supra note 47; Rennie Interview, supra note 152; Mellows Interview, supra note 6; Farrington Interview, supra note 6.

398. Powell Interview, supra note 47.

399. Rennie Interview, supra note 152. 
But culture is dynamic, not static, and some officials fear that university disputes might increasingly find themselves in civil courts. ${ }^{400}$ Now, students know what education costs, grants fall short of need, students are being asked to contribute, and so they more willingly scrutinize the education they receive. ${ }^{401}$ Over the last quarter-century, student protest changed from "collective and politically driven" to "individual and consumerist"; charters likely constituted a significant catalyst in this change. ${ }^{402}$ Even though The Further and Higher Education Charter for Scotland avoided the "institution-customer" terminology of its English parallel, ${ }^{403}$ the educational charter movement unquestionably contributed mightily to the notion of student qua consumer. As one university official put it, a charter yields the feeling that the student is a valued and paying customer. ${ }^{404}$ "It is a short step from the Charters and the funding arrangements to the view that students are consumers . . . in a contractual ... relationship with the institution." 405 The old notion of the university as a "social club" has yielded to a "new concentration" on the rights of the client to educational quality. ${ }^{406}$ Like other consumers, educational consumers increasingly question the quality of the purchased product. Anecdotal evidence indicates that charters, by their nature, encourage complaints. To compound matters, universities themselves have become more "rule-bound" and adversarial. ${ }^{407}$

Ellis John Powell, University Regent at Aberdeen, observes that civillaw seems more and more to "take over" from internal courts-from courtsmartial in the military, from consistory courts in the Church, and from academic and disciplinary "courts" at universities. ${ }^{408}$ As expectations increase and as students increasingly perceive themselves as having rights-both within and without the university-more litigation seems inevitable. ${ }^{409}$ Students' use, in dealing with university officials, of threats to sue may reflect a growing cultural adjustment to the idea of resort to the courts for relief. Telling too is the fact that all seven Scottish cases revealed by a computerized search covering the last forty-seven years arose during the

400. "The litigation culture is changing." Clark \& Quinault Interview, supra note 66. 401. Powell Interview, supra note 47.

402. Michael Smith, Charters in Higher Education, 1 U. \& C. EDUC. L. NETWORK REP. 3 (1996).

403. FARRINGTON, supra note 17 , at 133.

404. Rennie Interview, supra note 152.

405. Farrington, supra note 15 , at 2.

406. FARRINGTON, supra note 17 , at 4-5.

407. Dennis Farrington \& Frank Mattison, Introduction to UNIVERSITIES AND THE LAW, supra note 14 , at $\mathrm{xv}$.

408. Powell Interview, supra note 47.

409. Farrington Interview, supra note 6. 
nineties. ${ }^{410}$ This movement undoubtedly will find significant sustenance in the American cultural influence to which Scotland remains subject.

Of course, not all university officials view negatively the threat of student litigation. Dennis Farrington, Deputy Secretary and Clerk to the University Court at Stirling, argues that the threat should be seen as a "valuable shake-up," providing universities an opportunity to demonstrate, in an era of reduced resources, the quality of their educational process. Good internal procedures, he maintains, will significantly reduce, if not eliminate, the threat of litigation. ${ }^{411}$

\section{The Law}

Within the United Kingdom, Scots law remains a "distinct system" based heavily on Roman law and the influence of French and German scholars. The Treaty of Union in 1707 preserved this distinction, providing for the perpetual existence of Scots law and Scots courts. Nonetheless, English law supplanted Roman law as the most powerful influence on Scots legal development; the sway of Roman law waned and, at about the end of the seventeenth century, ended. The constant tendency toward harmonization has moved the laws of Scotland and England closer together. ${ }^{412}$ Reminiscent of the Anglo-American equity courts, the nobile officium of the High Court and the Court of Session provides a remedy where neither statute nor precedent affords one. ${ }^{413}$ Today, Parliament may limit a law's application to England or to Scotland. Too often Parliament passes, without sufficient thought, laws applicable to both. Great English influence over Scots law comes as well from the power of the House of Lords to hear appeals from Scottish civil courts, a power that has often been exercised to reverse. ${ }^{414}$

Since 1973, Scotland has also been under the influence of European Community law. ${ }^{415}$ With regard to that law, all cases in the United Kingdom's courts are vulnerable to a "preliminary reference" to the European Court of Justice. ${ }^{416}$ Separate from the European Community, the

410. See supra note 266.

411. Dennis Farrington, Introduction to 1 U. \& C. EDUC. L. REP. 2 (1996).

412. See BrUCE MCKaIN ET AL., SCOTS LAW FOR JouRNALISTS 1 (6th ed. 1995); MARSHALL, supra note 15, at 2, 5-6. WHITE \& WILLOCH, supra note 8, at 6-7, 22, and 28. The development of a Scots legal system different from, yet similar to, England's ended with the Wars of Independence beginning at the end of the thirteenth century and Edward I's subjugation of Scotland. MARSHALL, supra note 15, at 2 .

413. See MCKAIN ET AL., supra note 412 , at $155-56$.

414. MARSHALL, supra note 15 , at 7-8. By established custom, at least two Scottish law lords sit in the House of Lords. Id. at 42.

415. Id. at 7.

416. White \& WiLloch, supra note 8 , at 40. 
"European Court of Human Rights . . . implements The European Convention for the Protection of Human Rights and Fundamental Freedoms," often called the European Convention on Human Rights. ${ }^{417}$

Legislation specifically controlling universities in Great Britain has been, at least until lately, comparatively rare. This relative and noteworthy lack of legislation may stem from the fact that "the general powers and duties conferred by the principal Act (The Education Act 1944) were so far reaching. " 418 In any event, the Education Reform Act of 1988 placed on a statutory basis the relationship between universities and the Crown. ${ }^{419}$

Where can a student go once internal challenges have failed? Currently, only to the courts. ${ }^{420}$ Relationships between students, actual or potential, and their institutions in the United Kingdom present considerable complexity, especially in light of the many models of governance now prevailing. ${ }^{421}$ Clearly, one has no right to university admission, and universities need give no reasons for the rejection of a candidate's application. ${ }^{422}$ A student who has accepted an offer of admission from a university has a contract of admission with the institution. ${ }^{43}$ Once matriculated, the student may assume two distinct but related relationships with the institution. The first derives from contract; ${ }^{424}$ the second arises, at least when the student is a "corporator" in a chartered institution, from status, carrying rights independent of contract. ${ }^{425}$ The contractual relationship between the student and the institution becomes underlined, if not created, by the educational charters. That contract provides for instruction, along with a variety of ancillary services. This relatively complex agreement grows from a panoply of sources-the prospectus, oral statements, custom and practice, student handbooks, departmental literature, and even the institution's individual charter. That charter might not only add

417. Id. at $45-46$. For the enforceability of the ECHR "through the right of individual petition or at the instance of a signatory," see $i d$. at 94-95.

418. Henderson \& Mattison, supra note 14, at 9, 12 (quoting G. TAYLOR \& J. B. SAUNDERS, THE LAW OF EdUCATION 3 (1976)).

419. Id. at 13.

420. FARRINGTON, supra note 17 , at 53 .

421. Id. at 1.

422. See id. at 4-5. But see O'Reilly v. University of Glasgow (1995) (unreported), discussed in FARRINGTON, supra note 17, at 5.

423. Henderson \& Mattison, supra note 14, at 70; FARRINGTON, supra note 17, at 2 . No reasons need be given for rejecting a candidate for admission. Id. at 4 . 55.

424. For more on the contract of matriculation, see FARRINGTON, supra note 17, at 347 -

425. Henderson \& Mattison, supra note 14, at 70. See also FARRINGTON, supra note 17, at 327. The same effect may obtain at non-chartered institutions. See Henderson \& Mattison, supra note 14 , at 77 .

For a discussion of the rights of a foreign student against an institution in the United Kingdom, see Peter Kaye, Colleges in Court, 137 SoLIC. J. 816 (1993). 
its own terms to the contract, but color or define those originating elsewhere. ${ }^{426}$ Some of these potential sources of contractual terms, of course, and perhaps especially the institutional charters, might be seen more as "expressions of desire and intent than [as] statements of contractual obligation. " ${ }^{\prime 27}$ In any event, doctrine dating from the nineteenth century ${ }^{428}$ counsels that courts not imply terms into contracts whenever it is reasonable to do so, but only when business efficacy makes it necessary to do so. ${ }^{429}$ Nonetheless, in its contract with the student, the institution surely has at least impliedly agreed to employ reasonably competent professionals who will exercise reasonable care and skill. ${ }^{430}$

Even the enforcement of good order on campus rests on the student's agreement, under the contract of registration, to be bound by the institution's rules: ${ }^{431}$ "[U]niversities do not have an inherent power to discipline their students . . but only a contractual one." ${ }^{432}$ Indeed, one might consider "the entire individual-institutional relationship from first offer and acceptance to final graduation as 'a rolling contract which matures and changes shape in the course of its life.' 433 In any event, the contract between the student and the university reflects unequal parties and thus much resembles an adhesion contract, ${ }^{434} \mathrm{a}$ fact courts might notice in attempts to enforce that contract.

In simple terms, contractual matters go to the ordinary courts (and possibly, ultimately, on appeal to the European Court of Human Rights). ${ }^{435}$ Judicial review, on the other hand, reflects "the exercise of the court's

426. Smith, supra note 402, at 2-3. Accordingly, Mr. Smith argues, the "ideal charter from the point of view of the lawyer advising a university is a bland descriptive document, which deals with aspirations not expectations, and tries to say nothing. This will often be unacceptable to the students, and indeed to the institution itself." Id. at 3.

427. FARRINGTON, supra note 17, at 8. For a model contractual provision, see id. at 10 .

428. See The Moorcock, 13 PD 157 (1888), aff'd, 14 PD 64 (1889).

429. FARRINGTON, supra note 17 , at 11 .

430. Id. at 136.

431. Students commonly execute a form of undertaking to honor the rules of the institution. FARRINGTON, supra note 17 , at 368 . See, e.g., the University Oath at the University of Glasgow: "I solemnly promise that I will fulfill the requirements made by the Senatus Academicus . . . and will conform to its discipline . . ." GLASGOW CALENDAR: FEES \& INFORMATION, supra note 182, at 3. See also STIRLING HANDBOOK, supra note 12, at 17: "When you sign the registration form you agree to be bound by the University's rules and regulations ...." Separate undertakings may occur with regard to libraries, residential facilities, computer facilities, laboratories, and the like. See FARRINGTON, supra note 17, at 369.

432. Ustaran, supra note 212 , at 6.

433. Farrington, supra note 15, at 6 (quoting S. Arrowsmith, The University-Student Contract (1996)) (paper presented to the seminar "Key Issues in the Law of Higher Education," New College, Oxford, Mar. 27, 1996). For more on the institution-student contractual relationship, see FARRINGTON, supra note 17, at 330-47.

434. FARRINGTON, supra note 17 , at 350 .

435. See id. at $64,68$. 
inherent power at common law to determine whether action is lawful or not . . . "436 Public-law matters thus qualify for judicial review, ${ }^{437}$ triggered by an institution's statutory origins or the legislative underpinnings of the institutional power at issue. ${ }^{438}$ Such a determination allows the student to rely on more than the rules and regulations of the institution applicable to "what could hardly be described as a wholly balanced contractual relationship[ ]." 439 Public institutions discharging public functions thus become subject to judicial review on "conventional grounds," generally comprising illegality, irrationality, or procedural impropriety. ${ }^{440}$ Even so, since the same unfortunate (from the student's perspective) result might follow the court-ordered use of correct procedures, a judicial-review victory may prove to be an empty one. ${ }^{41}$ Because in Scotland contract enforcement and judicial review present two different procedures, discerning which is at issue becomes crucial and, to this day, sometimes difficult. In Naik $v$. University of Stirling, ${ }^{442}$ a tuition-fees case, the court found judicial review appropriate because of the tripartite relationship existing among: 1) the person on whom some authority to act has been conferred (here the University); 2) the person that conferred that authority (here The Queen, who granted the University its Royal Charter); and 3) the person for whose benefit the authority should be exercised (here the student). But this analysis did not prevail in Re Alistair Joobeen's Application, ${ }^{443}$ another tuition-fees case (involving Naik's boyfriend and the same institution). In Joobeen the court found that the dispute concerning the tuition fees involved "matters of simple right and obligation, requiring the Court's ordinary, and not its supervisory jurisdiction." 444 In such a case, contractual rights cannot be trumped by "any general equitable or supervisory power" of the court. ${ }^{445}$ In $N a i k$, however, the court remained unpersuaded that the matter involved only payment of fees and not, in addition or instead, the student's misconduct.

436. Regina v. University of London ex parte Vijayatunga, 1 Q.B. 322, 343 (1988) (Simon Brown, L.J.).

437. Farrington Interview, supra note 6.

438. Alex J. Carroll, The Abuse of Academic Disciplinary Power, NEw L.J. 729 (May 27, 1994).

439. Id. at 730 .

440. FARRINGTON, supra note 17 , at 15.

441. Id. at 16.

442. 1994 S.L.T. 449, 1993 Sess. Cas. (Outer House, June 22, 1993).

443. 1995 S.L.T. (Notes) 120, 1994 Sess. Cas. (Outer House, July 28, 1994).

444. Id. See generally FARRINGTON, supra note 17, at 18-19, 56-57.

445. 1995 S.L.T. (Notes) 120, 1994 Sess. Cas. (Outer House, July 28, 1994). 
As in the United States, ${ }^{446}$ Scottish courts have shown great reluctance to overturn the academic judgments of universities; ${ }^{447}$ addressing such appeals, Scottish courts have limited themselves to "ensuring that the academic decision has been reached following proper procedures. ${ }^{n 48}$ In $R e$ Ahmed Saleh, ${ }^{449}$ a student sought to overturn a university judgment that he not be allowed to revise and re-submit a failed thesis. The Court of Session, declining to interfere with academic judgment, dismissed the petition for judicial review. A later re-framing of the claim, in Ahmed Saleh $v$. University of Dundee, ${ }^{450}$ brought the same result. Since academic failure presents the area most likely to spawn legal action, ${ }^{451}$ this unreceptive judicial posture obviously provides considerable solace to universities.

Other academic disappointments also found little welcome in the courts. In Re Elaine Parks Carlton, ${ }^{452}$ a student denied an "Honours" degree attacked the process by which a subcommittee of the Academic Appeals Committee blocked her appeal from reaching the full Committee. Since the subcommittee had been given such discretion, its decision should stand, the court said, unless no reasonable subcommittee could have reached it-not the case here. In Re Conor Reilly, ${ }^{453}$ a disappointed applicant to medical school argued that the University of Glasgow had, in violation of the principles of natural justice, a "work experience" requirement not listed in the University's prospectus. The court sided with the University, finding that no such requirement had been imposed. Thus, in all four of the cases disclosed by a computer search and involving direct challenges of academic decisions, the institution prevailed.

446. See, e.g., Regents of Univ. of Mich. v. Ewing, 474 U.S. 214 (1985); Board of Curators of the Univ. of Mo. v. Horowitz, 435 U.S. 78 (1978); Washington v. Baruch, 633 N.Y.S.2d 286 (N.Y. App. Div. 1995); Esmail v. S.U.N.Y. Health Science Ctr., 633 N.Y.S. 2d 117 (N.Y. App. Div. 1995); and Karen M. Porter, Trend Favors Summary Adjudication of Lawsuits Challenging Academic Decisions, IV HIGHER ED. L. BULL. 3 (1995): "To discourage efforts to engage the judiciary in the management of academic determinations, the federal and state courts have long applied an especially rigorous scrutiny to complaints of students." The showing of bad faith crucial to judicial overturning of an institution's academic decision has rarely been made. Id. (citing Susan M. v. New York Law Sch., 556 N.E.2d 1104,1107 (N.Y. App. 1990).

447. FARRINGTON, supra note 17 , at 361 .

448. University of Aberdeen, Academic Appeals-Guidance Note, supra note 181, 22.

See FARRINGTON, supra note 17 , at 12 n.75.

449. 1992 Sess. Cas. (Outer House, Nov. 6, 1992) discussed in FARRINGTON, supra note 17 , at 19.

450. 1994 Sess. Cas. (Inner House-Extra Division, June 8, 1994).

451. FARRINGTON, supra note 17 , at 359.

452. 1994 S.L.T. (Notes) 549, 1993 Sess. Cas. (Outer House, Sept. 24, 1993).

453. 1995 Sess. Cas. (Outer House, Aug. 22, 1995). 
Though procedures and the conduct of officials in Scottish universities in fact reflect principles of natural justice, ${ }^{454}$ it remains unclear to what extent Scottish corporations, chartered or unchartered, may ignore those principles in excluding members. ${ }^{45}$ Though somewhat subjective, these principles reduce themselves to the right to notice of charges, the right to be heard in answer to those charges, and the right to a neutral hearing body. ${ }^{456}$

\section{Costs}

In Scotland, the financial costs-or at least the perceptions thereof-attending litigation further inhibit students from bringing suit. As one Scottish source puts it, "Most civil disputes are settled out of court, because litigation is slow, expensive and uncertain . . ."457 Interviews with university officials, however, bring no consensus on this point. One view holds that the expense indeed does contribute to the non-litigative culture. ${ }^{458}$ Another observes that Legal Aid will sponsor any student with a colorable claim. The student's venture presents no risk: If the student wins, the university pays the costs, and if the student loses, the university will not likely recover its costs, ${ }^{459}$ despite the general rule that assigns to the losing party the judicial expenses of the prevailing party. 460

Legal aid will be less available under new rules, ${ }^{461}$ thus reflecting a longstanding trend in Great Britain: In 1979, seventy-nine percent of Britons qualified for legal aid; only forty-seven percent did in 1990. Moreover, additional and significant cuts in the program's funding took place in 1993. Would-be "pursuers" (Scotland's plaintiffs) who do qualify for legal aid may nonetheless find it difficult to find a solicitor willing to work for the relatively frugal compensation provided by legal aid. Pursuers who do sue and prevail must reimburse the Legal Aid Fund for any expenses not covered

454. With regard to natural justice and disciplinary rules, see FARRINGTON, supra note 17 , at 366 .

455. Id. at 65 (citing Gaiman v. National Ass'n for Mental Health, 2 All E.R. 362, 380-

81 (1970)). But see Re Ahmed Saleh v. University of Dundee, 1994 Sess. Cas. (Inner House-Extra Division, June 8, 1994).

456. Robert Seaton, University Staff and Employment Law, in UNIVERSITIES AND THE LAW, supra note 14 , at 98-99:

457. WhITE \& WILLOCH, supra note 8, at 61.

458. Reynolds Interview, supra note 155, and Mellows Interview, supra note 6.

459. Farrington Interview, supra note 6. These costs are not negligible. In a recent case-which it won-the University of Stirling did not recover costs, though having spent approximately 100,000 pounds sterling on the project. Id.

460. WHITE \& WILLOCH, supra note 8, at 64,252 . For more on the assessment of costs, see $i d$. at 252.

461. Rennie Interview, supra note 152. 
by a judicial award of costs. As a result, even the winning party may finish with little or nothing of the recovery. ${ }^{462}$

Of course, the student might seek representation without recourse to legal aid. In some places, at least, a student can get an initial interview with a solicitor without cost. ${ }^{463}$ From then on, however, the case might well require significant resources. One thing is clear and at least partly explains (in addition to reflecting) the difference between the culture of litigation in Scotland and that in America: Scottish lawyers may not accept cases on a contingent-fee basis. ${ }^{464} \mathrm{It}$ is unlawful on the part of either the advocate or the solicitor to make an agreement calling for payment of a proportion of the proceeds. But "speculative actions" are permitted when there is a reasonable prospect of success. Such arrangements allow lawyers to provide service with the understanding that they will be paid only if successful. ${ }^{465}$

Just as England and Australia have their solicitors and barristers, the Scottish legal profession also deploys two branches, called solicitors, who give advice and generally appear only in lower courts, and advocates, the parallel to barristers. ${ }^{466}$ Advocates generally "receive instructions" only from a solicitor and not, therefore, directly from the client. ${ }^{467}$ Accordingly, a pursuer can end up paying for a solicitor and two barristers, since a senior advocate (Queen's Counsel) might insist on the support of a junior advocate. ${ }^{468}$ A pursuer who loses also faces the prospect of indemnifying the expenses of the "defender" (Scotland's defendant), who might in turn have employed a parallel group of three lawyers. In light of all of this, it is little

462. WHITE \& WILLOCH, supra note 8 , at $253-54,256$. For the specifics of income eligibility for legal aid in Scotland, see MARSHALL, supra note 15, at 56. Even those who qualify for legal aid must, depending on annual income and disposable capital, make a contribution to the Scottish Legal Aid Fund. Id. at 78. For more on Scottish legal aid generally, see id. at 71-82; and LEGAL AID (SCOTLAND) ACT 1986.

463. Clark \& Quinault Interview, supra note 66.

464. Interview with Christopher H. W. Gane \& Douglas Cusine, Professors of Law, Univ. of Aberdeen, in Aberdeen, Scot. (June 26, 1996). Interestingly, England, pursuant to government regulations introduced into Parliament by the Lord Chancellor, now allows "conditional fees" in personal-injury, insolvency and human-rights cases. The lawyer who loses receives no fee; the lawyer who wins recovers the "normal fee plus a special uplift, called a "success' fee." Fenton Bresler, British Thumbs-Up To "Conditional Fees, "NAT'L L.J., July 1, 1996, at A17-A18. See also Frances Gibb, Shake-up Aims to Curb 1.4bn 1 Costs of Justice, TIMES (London), July 3, 1996, at 6.

465. WHITE \& WILLOCH, supra note 8, at 234.

466. MCKAIN ET AL., supra note 412, at 6-7. See also WhITE \& WILlOCH, supra note 8, at 232-33. Advocates may not form partnerships but must practice independently. Id.

467. WHITE \& WILLOCH, supra note 8, at 235; MARSHALL, supra note 15, at 56. Accordingly, the solicitor must be present when the advocate consults with the client. Id.

468. WHITE \& WILLOCH, supra note 8, at 232. 
wonder that for most people civil litigation provides a "rare and unwelcome experience." 469

\section{CONCLUSION}

Scotland's universities, largely dependent on a decreasing governmental largesse, range from the ancient to the new. Their governing boards generally include significant representation of both off-campus and on-campus constituencies. At many campuses, two of the three primary offices-those of the Chancellor and of the Rector-tend to be largely honorific. Internal procedures, both academic and disciplinary, provide students with abundant protections in disputes with the university.

In dealing with their students' academic and disciplinary problems, Scottish universities have avoided litigation to an extent that would startle American lawyers. This happy situation results from diffused governance, restrained jurisdiction, meaningful internal remedies, a cultural disinclination toward litigation, a law relatively unreceptive to student complaints, and the prohibitive costs of legal recourse. Nonetheless, greater expectations of rights among students-spurred in part by the educational charters and burgeoning formal procedures, increasing use of threats to sue, and a modest though real growth in actual litigation send sure warning signs: Dramatic changes in the culture of litigation among Scottish students become increasingly possible, if not likely.

Litigation represents the most divisive, the most cumbersome, and the slowest medium for the resolution of intra-university quarrels. It is also the most expensive. Especially in a time of diminishing resources, therefore, universities must fervently seek additional devices, and reinforce existing ones, for avoiding lawsuits brought by students to challenge academic and disciplinary disputes. The principle of subsidiarity, through which universities strive to resolve matters at the lowest level possible, presents a solid defense to much litigation. Appeals that truly hear the student and right discovered wrongs provide an important safeguard. When litigation does arise, universities must continue to establish and underline the principle that academic judgments are best left to the experts, that is, the academics in the institution itself; absent irrationality or arbitrariness, courts should leave undisturbed academic disputes brought to them by students. Universities should give every consideration to the establishment of some form of "arbiter" who, borrowing from and improving upon the British or Australian Visitor, might provide, pursuant to agreement with the entering student, the final word on any ensuing academic or disciplinary disputes between the student and the university. In this quest to keep courts from exerting 
jurisdiction within the academy, both the university and the student-as well as the concept of community-have much to gain. 